\title{
NGF-withdrawal induces apoptosis in pancreatic beta cells in vitro
}

\author{
D. Pierucci ${ }^{1}$, S. Cicconi ${ }^{1}$, P. Bonini ${ }^{1}$, F. Ferrelli ${ }^{1}$, D. Pastore ${ }^{1}$, C. Matteucci ${ }^{2}$, L. Marselli ${ }^{3}$, P. Marchetti ${ }^{3}$, F. Ris ${ }^{4,5}$, \\ P.Halban ${ }^{4}$, J. Oberholzer ${ }^{5}$, M.Federici ${ }^{1}$, F. Cozzolino ${ }^{3,6}$, R. Lauro ${ }^{1}$, P. Borboni ${ }^{1}$, L. N.J. L. Marlier ${ }^{1,6}$ \\ ${ }^{1}$ Laboratory Molecular Medicine, Department of Internal Medicine, University of Rome "Tor Vergata", Rome, Italy \\ ${ }^{2}$ Department of Experimental Medicine and Biochemical Sciences,University of Rome "Tor Vergata", Italy \\ ${ }^{3}$ Department of Endocrinology and Metabolism, University of Pisa, Italy \\ ${ }^{4}$ Louis-Jeantet Research Laboratories, University Medical Center, Geneva, Switzerland \\ ${ }^{5}$ Division of Surgical Investigation, Clinic of Digestive Surgery, Geneva, Switzerland \\ ${ }^{6}$ National Research Council (CNR), Institute of Neouroscience and Molecular Medicine, Rome, Italy
}

\section{Abstract}

Aims/hypothesis. Using primary cultures of human pancreatic islets, purified human pancreatic beta cells and the mouse $\beta$ TC6-F7 cell line, we analysed the expression of nerve growth factor, (NGF/NGF) receptors in beta cells. To investigate whether NGF could sub-serve an autocrine antiapoptotic role in beta cells, we studied the effects of NGF withdrawal using a neutralizing monoclonal anti-NGF antibody.

Methods. The expression of NGF and NGF receptors (gp140 Trk-A and $\mathrm{p} 75^{\mathrm{NTR}}$ ) were analysed by RT-PCR and immunofluorescence. Pulse-chase experiments and beta cell/PC12 co-cultures were used to investigate NGF production and secretion from beta cells. Possible apoptosis induced by NGF withdrawal was monitored by phosphatidylserine translocation, nucleosomal formation, DNA laddering and FACS analysis. Involvement of transcription/translation mechanisms were investigated as well as the gp140 Trk-A required. Finally, signal transduction pathways typically involved in apoptotic mechanisms were analysed by western blot analysis.
Results. We show that NGF and both NGF receptors, gp $140^{\text {Trk-A }}$ and $\mathrm{p} 75^{\mathrm{NTR}}$ are expressed in beta cells where NGF is produced and secreted in a biologically active form. NGF-withdrawal induces beta-cell transcription/translation independent apoptosis but mediated by gp140Trk-A. Analysis of signal transduction pathways revealed that NGF withdrawal inhibits the PI3-K, protein kinase B (AKT), Bad survival pathway and activates c-Jun kinase (JNK) whereas ERKs and p38 mitogen-activated protein kinase (MAPK) are not affected. Moreover, Bcl-XL, but not Bcl-2 protein expression are reduced.

Conclusion/interpretaiton. We suggest that the integrity of the NGF/NGF receptor system and NGF bioavailability participate in controlling beta-cell survival in culture which represents a key issue for improving possibilities for transplantations in the treatment of diabetes. [Diabetologia (2001) 44: 1281-1295]

Keywords Islet cell, nerve growth factor, nerve growth factor receptors, diabetes mellitus, apoptosis, cell death, protein-tyrosine kinase, proto-oncogene proteins c-bcl-2, signal transduction, phosphorylation.
Beta cells originate from precursor cells in the pancreatic ducts, although the possibility of an early migration of the neuroectodermal cells to the endoderm has not been completely ruled out [1-3]. These cells

Received: 3 May 2001 and in revised form: 19 June 2001

Corresponding author: Lionel NJL. Marlier, Dept. Internal Medicine, University of Rome "To Vergata", Via di Tor Vergata, 135, 00133 Rome - Italy, E-Mail: I.marlier@in.rm.cnr.it, Tel.: (+39) 0672596530, Fax: (+39) 0672596538 share many similarities with neurons such as the expression of neuron-specific molecules, that is tyrosine hydroxylase or dopamine $\beta$-hydroxylase. They are electrically excitable like neurons and insulin release is a process resembling neurotransmitter release, involving cell depolarization and vesicle exocytosis [4]. Beta cells and neuronal cells could be sensitive to the same growth and differentiation factors since specific transcriptional activators (Islets1, Pax-6 and Beta2) are expressed in beta cells and neurons, whereas the transcriptional repressor factor NRSF/ 
REST (neuron-restrictive silencing factor or repressor element silencing transcription factor) is absent in both neuronal and beta cells which represents a common mechanism for controlling gene expression [5-10].

Nerve growth factor (NGF), the archetypal member of a family of factors important for the differentiation and survival of neurons and neural crest-derived cells [11,12], exerts its biological effects through specific cell surface receptors: $\mathrm{p} 75^{\mathrm{NTR}}$ (also named p75), the low affinity NGF receptors, and gp140 Trk-A (also named Trk-A), the high affinity NGF receptor which combines with $\mathrm{p} 75^{\mathrm{NTR}}$ to form a receptor complex with full biological activity [13].

It has been shown that beta cells express functional receptors for NGF and that NGF exerts various effects on beta cells such as the induction of neuronlike differentiation, stimulation of sodium current and enhancement of early responsive gene expression ( NGF-1A and c-fos) [1, 14-19].

Maintaining and expanding functional beta cells in vitro is one of the major goals in beta-cell transplantation studies; this requires knowledge of beta-cell growth potential in culture conditions and of possible growth factors involved in such processes. We therefore characterized the expression of NGF/NGF receptors in human islets and human purified beta cells as well as in an insulinoma cell line ( $\beta$ TC6-F7 cells) and we show that NGF is synthesized and released from beta cells in a biologically active form. Furthermore we studied the effect of NGF deprivation on beta cell survival.

We also investigated the signal transduction pathways involved during NGF withdrawal-induced apoptosis. The NGF can activate several intracellular signalling transduction systems such as the mitogen-activated protein kinase (MAPK) including extracellular signal-regulated kinase 1 and 2 (ERK1-2) [20], the p38MAPK [21] or c-jun NH2-terminal-protein kinase (JNK) [22]. NGF withdrawal has been associated with modulation of MAPK in PC12 cells $[23,24]$ and has been shown to modulate the status of $\mathrm{Bcl}-2$ p38MAPK-dependant phosphorylation [25].

Through binding to its high affinity receptor gp140 Trk-A, NGF is known to activate phosphatidylinositol 3-kinase (PI3-K) [26] whose activation is required, for example, for PC 12 cell survival [27]. In NGF-dependent sympathetic neurons, the PI3-K/ protein kinase (AKT) pathways seem fundamental for cell survival [28]. AKT is able to phosphorylate $\mathrm{Bad}$, a proapototic member of the Bcl-2 protein family. Once it is phosphorylated, Bad remains bound to the cytosolic 14-3-3 protein and cannot exert its proapoptotic function by freeing $\mathrm{Bcl}-\mathrm{X}_{\mathrm{L}}$ or $\mathrm{Bcl}-2$ [29, 29-32].

Thus to elucidate the possible signal transduction system involved in beta-cell apoptosis on NGF withdrawal, we analysed the phosphorylation status and/ or kinase activity of ERK, p38MAPK and JNK as well as the PI3-K/AKT/Bad pathway. Finally, we measured the cellular content for Bcl-2 and Bcl- $\mathrm{X}_{\mathrm{L}}$ in $\beta$ TC6-F7 cells exposed to anti-NGF treatment.

\section{Materials and methods}

Human pancreatic islets isolation and cell dispersion. Adult human islets were obtained from cadaver donors at the University of Pisa, Italy (four men aged $55 \pm 5$ years who died from stroke). The islets were prepared by a modification of the procedures for preparing large mammal islets [33], using collagenase (Collagenase P, Boehringer-Mannheim, Mannheim, Germany) $[34,35]$.

Briefly, for the islet purification procedure, tissue was loaded into $250 \mathrm{ml}$ plastic conicals and resuspended in Histopaque 1.077 (Sigma-Aldrich, Milan, Italy) or 20\% Hank's buffer saline salt (HBSS, Invitrogene, Milan, Italy), topped with $40 \mathrm{ml}$ HBSS. After centrifugation, the islets were recovered at the interface between the Histopaque and the HBSS layers, washed with HBSS by centrifugation and finally resuspended in M199 (Invitrogene) culture medium. For cell dispersion, the islets were washed and resuspended in Kreb's ringer bicarbonate solution (KRB; Invitrogene) without $\mathrm{Ca}^{++}$in the presence of $1 \mathrm{mmol} / \mathrm{l}$ EGTA and digested with Trypsin/DNAs. The dissociation was stopped by adding fresh KRB containing $1.67 \mathrm{mmol} /$ $1 \mathrm{Ca}^{++}$and $1 \%$ fetal calf serum (FCS; Invitrogene) and cells were resuspended in M199 culture medium (Invitrogene) to be cultured until use.

Isolation and sorting of human pancreatic beta cells. Human islet isolations (two men aged 23 and 65 years and a woman aged 52 years who died from a traffic accident) were carried out in the Division of Surgical Investigation at the University hospital of Geneva (Switzerland) according to standard procedures [36] with minor modifications. The final islet preparation was resuspended in University of Wisconsin preservation solution at $4^{\circ} \mathrm{C}$ and islets were purified by a discontinuous Ficoll gradient on a cell separator; densities used were: 1.108 (bottom layer), 1.096, 1.037, 1.006 (top layer). Islets were cultured for up to $24 \mathrm{~h}$ and purity and number were assessed as described [37]. Islets were then dissociated and infected with a recombinant adenovirus expressing green fluorescent protein (GFP) under the control of the rat insulin promotor (RIP) [38]. After expression of the GFP, assessed by inverted fluorescence microscopy, cells were harvested and sorted using a FACStar-Plus (Beckton Dickinson, Geneva, Switzerland); beta cells expressing GFP were then immediately processed for RNA extraction and successive RTPCR experiments.

$\beta$ TC6-F7 cell cultures. $\beta$ TC6-F7 cells (kindly provided by Dr. S. Efrat, Tel Aviv University, Israel) deriving from transgenic mice expressing SV40 large T antigen under the control of the insulin promoter, were cultured as described previously and used at passages 35-47 during which physiological glucose responsiveness is maintained $[39,40]$.

PC12 cell cultures. PC12 cells were cultured on a collagen matrix in RPMI 1640 medium (Invitrogene) supplemented with $5 \%$ fetal calf serum (FCS), $10 \%$ horse serum (HS), 50 IU penicillin and $50 \mu \mathrm{g} / \mathrm{ml}$ streptomycin at $37{ }^{\circ} \mathrm{C}$ in an atmosphere of $95 \%$ humidified air and $5 \% \mathrm{CO}_{2}$. Half of the medium was renewed daily and cells were subcultured weekly. 
$\beta$ TC6-F7/PC12 co-culture. For $\beta$ TC6-F7/PC12 co-culture experiments, PC12 cells were seeded in collagen-coated multiwell plates (Falcon, Milan, Italy) in DMEM containing $11.1 \mathrm{mmol} / \mathrm{l}$ glucose and supplemented with $15 \% \mathrm{HS}, 5 \%$ FCS, $50 \mathrm{IU}$ penicillin and $50 \mu \mathrm{g} / \mathrm{ml}$ streptomycin (Invitrogene). $\beta$ TC6-F7 cells were seeded in cell culture inserts $(0.1 \mu \mathrm{m}$ pore size, Falcon) in the same medium. After 48 h, $\beta$ TC6-F7 inserts were transported over the PC12 multiwell plates and co-cultured for 5 days.

$R N A$ preparation and RT-PCR analysis of NGF, gp140 Trk-A and $p 75^{N T R}$ total RNA was extracted from $\beta$ TC6-F7 cells, human islets and purified human beta cells by the guanidium thiocyanate method [41] and used for reverse transcription - polymerase chain reaction analysis (RT-PCR). Briefly, $100 \mathrm{ng}$ RNA from $\beta$ TC6-F7 cells or 50 ng RNA from human material, were reverse transcribed for $1 \mathrm{~h}$ at $42^{\circ} \mathrm{C}$ by $200 \mathrm{U}$ MMLV reverse transcriptase (SuperScript II, Invitrogene) in the presence of $2.5 \mu \mathrm{m}$ random hexamers and $200 \mu \mathrm{mol} / 1$ nucleotides (Amersham Pharmacia Biotech, Milan, Italy). cDNA was successively PCR-amplified using 2.5U Platinium Taq PCR-Supermix High Fidelity (Invitrogene) or Hot Start (Qiagen, Milan, Italy) for human material, for 40 to 50 cycles, in 15 pmol specific primers for NGF, gp $140^{\text {Trk-A }}$ or p $75^{\mathrm{NTR}}$ in a Perkin Elmer 2400 thermal cycler. Primers were based on the reported sequences. For mice material, sequences were as follows: NGF, 5' (5'-AAGGACGCAGCTTTCTATAC) and 3' (5'TGTGGAAGACTGGGTGGGT); gp140 ${ }^{\text {Trk-A }}$, 5' (5'-GTGCTCAATGAGACCAGCTTC) and 3' (5'-CTTCAGTGCCTTGACAGCCAC); p75 NTR, 5' (5'- GAGCCAACCAGAGCGTGTG) and 3' (5'-GGGGATGTGGCAGTGGAC) [42]. For human material, sequences were: NGF, 5' (5'-ATACAGGCGGAACCACACTCAGAG) and 3' (5'-TCCCAACACCATCACCTCCTTG); gp140 ${ }^{\text {Trk-A }}$, 5' (5'-ACGGAGAAACAAGTTTGG) and 3' (5'- CTTACGGTACAGGATGCTC); p75 ${ }^{\mathrm{NTR}}, 5$, (5'-ATGGGGGCAGGTGCCA) and 3' (5'-TCACACCGGGGATGTGGC). At the end of the amplification reaction, aliquots of the PCR products $(15 \mu \mathrm{l})$ were resolved onto $1.5 \%$ agarose-TBE gel in the presence of ethidium bromide and analysed using a Fluor-S imaging system (Bio-Rad Laboratories, Hercules, Calif., USA). In control experiments, to exclude possible DNA contamination's, RTPCR was carried out without MMLV during the reverse transcription step.

Biosynthetic labelling of NGF. After 3 days in culture, $\beta$ TC6F7 cells were starved for $3 \mathrm{~h}$ in methionine-/cystein-free medium (Invitrogene). Then the medium was removed and replaced by fresh methionine-free or cysteine-free medium, containing $\left[{ }^{35} \mathrm{~S}\right]$ methionine and $\left[{ }^{35} \mathrm{~S}\right]$ cysteine (Amersham Pharmacia Biotech, $1 \mathrm{mCi}$ each) for $15 \mathrm{~h}$. At the end of the incubation period the culture medium was collected and the cells were lysed in ice cold Nonidet P-40 (NP-40) lysis buffer (1.5\% NP-40, $10 \%$ glycerol, $2 \mathrm{mmol} / \mathrm{l}$ phenylmethylsulfonyl fluoride (PMSF), $2 \mathrm{mmol} / 1 \mathrm{Na}_{3} \mathrm{VO}_{4}, 2 \mathrm{mmol} / \mathrm{l} \mathrm{EDTA}, 10 \mathrm{mmol} / \mathrm{l}$ sodium pyrophosphate, $10 \mathrm{mmol} / \mathrm{l}$ sodium fluoride and $8 \mu \mathrm{g} / \mathrm{ml}$ leupeptin). Culture medium and cell extracts were immunoprecipitated using a monoclonal anti-NGF antibody immobilized onto CNBr-coupled protein A-sepharose (Amersham Pharmacia Biotech) for $2 \mathrm{~h}$ at $4^{\circ} \mathrm{C}$ on a rocking platform [43]. Sepharose beads were collected by centrifugation, then washed twice in $50 \mathrm{mmol} / \mathrm{l}$ Tris- $\mathrm{HCl}(\mathrm{pH}=7.5), 0.02 \% \mathrm{NP}-40$ and once in $5 \mathrm{mmol} / \mathrm{l}$ Tris- $\mathrm{HCl}, 0.02 \% \mathrm{NP}-40$. Samples were denatured by boiling for $3 \mathrm{~min}$ in gel-loading buffer $(50 \mathrm{mmol} / \mathrm{l}$ Tris- $\mathrm{HCl}, \mathrm{pH}=6.8,100 \mathrm{mmol} / 1 \mathrm{DTT}, 2 \% \mathrm{SDS}$, $0.1 \%$ bromophenol blue and $10 \%$ glycerol) and analysed onto $15 \%$ SDS-PAGE.
Antibodies. Anti-Insulin specific antibody was raised in guinea pig. It recognizes insulin from several species and has been extensively used and characterized for RIA application [44].

Anti-NGF antibody is a monoclonal antibody produced and purified in our laboratory which has been used and characterized extensively [43,45,46].

Anti-p $75^{\text {NTR }}$ and anti-gp140 ${ }^{\text {Trk-A }}$ specific antibodies were purchased from Santa Cruz Biotechnology (Santa Cruz, Calif., USA, USA). The goat polyclonal anti-p $75^{\mathrm{NTR}}$ antibody (sc6188 ) is reactive with mouse, rat and human p $75^{\mathrm{NTR}}$. It is directed against an epitope mapping amino acids 408-427 located at the carboxy terminus of the human molecule and does not cross-react with other known growth factor receptors. The rabbit antibody, gp140 Trk-A $(\mathrm{sc}-118$ ) is specific for the mouse, rat and human gp140 ${ }^{\text {Trk-A }}$ protein and was raised against a peptide which corresponds with amino acids 763-777 mapping adjacent to the carboxy terminus of the human precusor form of gp140 Trk-A . It does not cross-react with other neurotrophin receptors (Trk-B or Trk-C). These two antibodies have been characterized by immunocytochemistry and functional assay $[17,19,47,48]$.

Secondary antibodies were from Jackson Immunoresearch Laboratories (West Grove, Pa., USA). For insulin immunolabelling, rhodamine (TRITC)- or fluorescein (FITC)-conjugated $\mathrm{F}\left(\mathrm{ab}^{\prime}\right) 2$ donkey anti-guinea pig antibodies were used (706-026-148 and 706-096-148, respectively). For gp140 Trk-A immunolabelling, FITC- or phycoerythrin (PE)-conjugated $\mathrm{F}\left(\mathrm{ab} \mathrm{b}^{\prime}\right) 2$ donkey anti-rabbit antibody was used (711-096-152 and $711-116-152$, respectively) whereas for p $75^{\text {NTR }}$, FITC- or PE-conjugated $\mathrm{F}(\mathrm{ab}$ ') 2 donkey anti-goat antibody was used (705-096-147 and 705-116-147, respectively).

For western blot analysis, gp140 ${ }^{\text {Trk-A }}$ was revealed by a goat anti-rabbit secondary antibody horseradish peroxidase-conjugated and $\mathrm{p} 75^{\mathrm{NTR}}$ was revealed by a rabbit anti-goat secondary antibody peroxidase-conjugated (Sigma Aldrich, Milan, Italy, A5420).

For signal transduction analysis, anti-p44/42 MAP kinase antibody was from New England Biolabs (Celbio, Milan, Italy; NEB 9102) as well as anti-phospho-p44/42 MAP kinase (Thr202/Tyr204; NEB 9101S) antibody, anti-JNK antibody (NEB 9250), anti-Akt antibody and anti-phospho-Akt (Ser473) antibody (respectively NEB 9271 and 9271S), anti-Bad and anti-phospho-Bad (Ser-136) (respectively BEB 9290 and NEB 9295S). Secondary antibodies were goat anti-rabbit or donkey anti-rabbit antibody HRP-conjugated (Amersham Pharmacia Biotech).

Monoclonal anti-Bcl-2 antibody was from Trevigene (2290MC-100; Trevigen Gaithersburg, Md., USA) and anti-Bcl- $\mathrm{X}_{\mathrm{S} / \mathrm{L}}$ was from Santa Cruz (sc-634).

Western blot analysis. $\beta$ TC6-F7 cells were lysed in Triton-X 100 lysis buffer $(150 \mathrm{mmol} / \mathrm{l} \mathrm{NaCl}, 10 \mathrm{mmol} / \mathrm{l} \mathrm{Tris} \mathrm{pH} 7.4,5 \mathrm{mmol} / 1$ EDTA pH 8.0, $1 \%$ Triton-X 100, 1 mmol/l PMSF).

Lysate was diluted 1:1 in a 2-mercaptoethanol laemmli

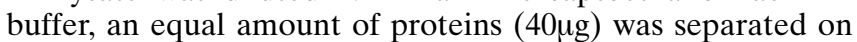
$7 \%$ SDS poly-acrylamide gel (PAGE) and transferred on nitrocellulose membranes. Uniform loading of proteins was verified by staining filters with "Ponceau". Membranes were blocked in TBST $(10 \mathrm{mmol} / \mathrm{l}$ Tris- $\mathrm{HCl}, \mathrm{pH} 7.5,100 \mathrm{mmol} / \mathrm{l}$ $\mathrm{NaCl}, 0.1 \%$ Tween 20 ) containing $5 \%$ non-fat dried milk, filters were incubated overnight with the primary anti-gp $140^{\text {Trk- }}$ $\mathrm{A}$ and anti-p $75^{\mathrm{NTR}}$ antibodies (1:80 and 1:100), washed in TBST and subsequently incubated for $1 \mathrm{~h}$ with the secondary antibody (1:50 and 1:100). The protein bands, gp140 ${ }^{\text {Trk-A }}$ and $\mathrm{p} 75^{\mathrm{NTR}}$ were visualized on autoradiographies with a chemiluminescent reagent detection system (ECL, Amersham Phar- 
macia Biotech). Apparent molecular weight was compared with the molecular size markers (Invitrogene).

Total Bad, phospho-Bad, total-JNK, total-p38, total ERK, phospho-ERK, Bcl-2 and $\mathrm{Bcl}-\mathrm{X}_{\mathrm{L} / \mathrm{S}}$ were analysed by western blot as reported above at various time-points after anti-NGF treatment and according to the recommendations of the manufacturers for antibodies dilutions.

JNK activity assay. JNK activity was studied using a non radioactive kit assay (SAPK/JNK assay, New England Biolabs) measuring c-Jun phosphorylation at Ser63. $1 \times 10^{6} \beta$ TC6-F7 cells were seeded in 6-cm dishes (Falcon, Milan, Italy); after $72 \mathrm{~h}$ the culture medium was removed and replaced by fresh serum-free medium containing anti-NGF antibody $(10 \mu \mathrm{g} / \mathrm{ml})$ for 15', 30', $1 \mathrm{~h}$ or $2 \mathrm{~h}$. Control cells were incubated with complete or serum-free medium without anti-NGF antibody.

After treatments, cells were washed with ice-cold PBS and cellular extracts were prepared by scraping cells in lysis buffer (Tris-acetate $20 \mathrm{mmol} / \mathrm{l} \mathrm{pH} \mathrm{7.5,} \mathrm{NaCl} 150 \mathrm{mmol} / \mathrm{l}$, EDTA $1 \mathrm{mmol} / 1$, EGTA $1 \mathrm{mmol} / 1$, sodium-pyrophosphate $2.5 \mathrm{mmol} /$ 1, Ortovanadate $1 \mathrm{mmol} / \mathrm{l}, \quad \beta$-Glycerolphosphate $1 \mathrm{mmol} / \mathrm{l}$, NaF 100 mmol/l, PMSF $1 \mathrm{mmol} / \mathrm{l}$, leupeptin $1 \mu \mathrm{g} / \mathrm{ml}$ ).

After sonication, cellular extracts were centrifuged for $10 \mathrm{~min}$ at $13000 \mathrm{~g}$ at $4{ }^{\circ} \mathrm{C}$ and supernatants were recovered.

Of total protein $500 \mu \mathrm{g}$ were immunoprecipitated with $3 \mu \mathrm{g}$ of GST-Jun (aa 1-89) fusion protein beads overnight at $4{ }^{\circ} \mathrm{C}$.

Then samples were microcentrifugated for $30 \mathrm{~s}$ at $4^{\circ} \mathrm{C}$ and the pellets were washed once with lysis buffer and once with kinase buffer $\left(\mathrm{MgCl}_{2} 10 \mathrm{mmol} / \mathrm{l}\right.$, Tris pH $7.525 \mathrm{mmol} / \mathrm{l}, \beta$-Glycerolphosphate $5 \mathrm{mmol} / \mathrm{l}$, Ortovanadate $0.1 \mathrm{mmol} / \mathrm{l}$, DTT $2 \mathrm{mmol} / \mathrm{l})$. Pellets were suspended in kinase buffer and supplemented with ATP $200 \mu \mathrm{mol} / \mathrm{l}$. After incubation at $30^{\circ} \mathrm{C}$ for $30 \mathrm{~min}$, reaction products were separated by SDS-PAGE on a $12 \%$ polyacrylamide gel and analysed by western blot, using phospho-c-Jun antibody.

p38MAPK activity assay. p38MAPK activity was studied using a non-radioactive kit (New England Biolabs) measuring phosphorylation of ATF-2 at Thr71.

Cells were processed as described for JNK except that the total protein was immunoprecipitated with $2 \mu \mathrm{g}$ of immobilized phospho-p38 MAP kinase (Thr180/Tyr182) monoclonal antibody overnight at $4{ }^{\circ} \mathrm{C}$.

Pellets were finally suspended in kinase buffer supplemented with ATP $200 \mu \mathrm{mol} / 1$ and $2 \mu \mathrm{g}$ of ATF-2 fusion protein. After incubation at $30{ }^{\circ} \mathrm{C}$ for $30 \mathrm{~min}$, reaction products were separated by SDS-PAGE on a $12 \%$ polyacrylamide gel and analysed by western blot, using phospho-ATF-2 antibody.

Immunofluorescence studies. For immunofluorescence studies, $\beta$ TC6-F7 cells or human dispersed beta cells were seeded in poly-D-lysine-coated Lab Teck eight-well chamber slides (Nalge Nunc International, Naperville, Ill., USA) and cultured for $24 \mathrm{~h}$.

Cells were washed three times in ice-cold PBS and fixed in ice-cold freshly prepared $4 \%$ paraformaldehyde-PBS for 20 min. Permeabilization was done in $0.1 \%$ Triton in PBS for $1 \mathrm{~min}$. After three washes in PBS, cells were exposed to the appropriate dilution of primary antibodies in incubation buffer (BSA $3 \%$ in PBS) for $1 \mathrm{~h}$ at room temperature. Cells were double labelled for insulin and gp $140^{\text {Trk-A }}$, insulin and $\mathrm{p} 75^{\mathrm{NTR}}$ or $\mathrm{p} 75^{\mathrm{NTR}}$ and gp $140^{\text {Trk-A }}$. After three washes in PBS, cells were exposed to secondary antibodies in the same buffer for $1 \mathrm{~h}$ at room temperature. Preparations were mounted with $70 \%$ glycerol in PBS and immediately observed. Images were acquired and processed using selective immunofluorescent filters for FITC, TRITC or PE with a digital CCD camera connected to an Olympus-based image analysis system.
Analysis of phosphatidylserine externalization. Dissociated human islets or $\beta$ TC6-F7 cells $\left(10^{5}\right.$ cells $\left./ \mathrm{ml}\right)$ were seeded in polyD-lysin-coated Lab-Teck eight-well chamber slides in culture medium. After $24 \mathrm{~h}$, the medium was removed and serum free fresh medium was added containing anti-NGF antibody for 30 or $120 \mathrm{~min}$. At the end of the treatments, cells were washed with PBS and externalization of phosphatidylserine on the plasma membrane of living cells was determined by ApoAlert Annexin V Apoptosis kit (Clontech, Palo Alto, Calif., USA); PS translocation toward the outer layer of the membrane was detected by fluorescent microscopy, thanks to the binding of a FITC conjugated Annexin V.

The beta-cell phenotype in human islets was then identified by insulin-like immunoreactivity labelling. After Annexin V binding step, islets were washed three times in ice-cold PBS and fixed in ice-cold freshly prepared $4 \%$ paraformaldehydePBS for 20 min. A mild permeabilization was done with $0.1 \%$ Triton in PBS for 1 min. After three washes in PBS, cells were incubated for $1 \mathrm{~h}$ at room temperature with an anti-insulin specific antibody [44] in incubation buffer (BSA $3 \%$ in PBS). Primary antibody was revealed by a TRITC-conjugated secondary antibody for $1 \mathrm{~h}$ at room temperature (TRICT-conjugated F(ab')2 donkey anti-guinea pig, Jackson Immunoresearch Laboratories 706-096-148). Preparations were mounted with $70 \%$ glycerol in PBS and immediately observed. Images were acquired and processed using selective immunofluorescent filters for FITC or TRITC with a digital CCD camera coupled to an Olympus-based image analysis system.

Nucleosomal formation assay. $\beta$ TC6-F7 cells were seeded in 24-well plates; after $48 \mathrm{~h}$ the culture medium was removed and replaced by fresh serum-free medium containing antiNGF antibody for 6, 12 or $24 \mathrm{~h}$. Control cells were incubated with complete or serum-free medium in the absence of antiNGF antibody.

At the end of the treatments, cells were lysed and nucleosomal formation was assayed by quantitative in vitro measurements of cytoplasmatic histone-associated DNA fragments (Cell Death Detection ELISA ${ }^{\text {PLUS }}$, Roche, Milan, Italy), according to the manufacturer's recommendations. Nucleosomal enrichment expressed in ordinate represents the ratio mean OD values from experimental cells-to-mean OD values from control cells, i. e. cells cultured in complete medium conditions.

In a second set of experiments, cells cultured in complete medium were treated with $50 \mu \mathrm{mol} / \mathrm{l}$ Tyrphostin AG879 (Calbiochem, La Jolla, Calif., USA) for $24 \mathrm{~h}$ to block the NGF-dependent gp140 Trk-A tyrosine phosphorylation or with $50 \mu \mathrm{mol} / \mathrm{l}$ Tyrphostin A1 (Calbiochem, La Jolla, CA, USA), an inactive inhibitor of gp140 Trk-A tyrosine phosphorylation, as a negative control [49].

In a third set of experiments, $\beta$ TC6-F7 cells were cultured for $48 \mathrm{~h}$ in complete medium; thereafter the medium was replaced with fresh complete medium containing either $1 \mu \mathrm{g} / \mathrm{ml}$ actinomycin D (AMD, Sigma Aldrich) or $5 \mu \mathrm{g} / \mathrm{ml}$ cycloheximide (CHX, Sigma Aldrich) for $1 \mathrm{~h}$. Cells were then washed and serum-free fresh medium containing anti-NGF antibody $(15 \mu \mathrm{g} / \mathrm{ml})$ was added for $6 \mathrm{~h}$. Subsequently nucleosomal formation was assayed as described above.

Analysis of DNA laddering. $\beta$ TC6-F7 cells were seeded in six multiwell plates at a density of $2 \cdot 10^{5} / \mathrm{ml}$. After $48 \mathrm{~h}$ the culture medium was replaced with fresh serum-free medium containing $10 \mu \mathrm{g} / \mathrm{ml}$ anti-NGF antibody or mouse IgG (control) for 6,12 or $24 \mathrm{~h}$. Untreated dishes were processed in parallel to control DNA preparation. At the end of the treatments, cells were washed twice in PBS and lysed with $10 \mathrm{mmol} / \mathrm{l}$ Tris$\mathrm{HCl}, 10 \mathrm{mmol} / \mathrm{l}$ urea and $20 \%$ Triton-X 100. Genomic DNA 
was extracted using high pure PCR template preparation kit (Roche, Milan, Italy) following the manufacturer's recommendations, quantified by spectrophotometer and analysed on $1.2 \%$ agarose [0.5 mol Tris Borate EDTA (TBE) gels electrophoresis to ensure DNA purity].

Pure DNA was analysed by the ApoAlert LM-PCR ladder assay kit (Clontech) according to the manufacturer's instructions to reveal nucleosomal ladders in apoptotic cells. Briefly, in a first step, 5' and 3' adapters oligonucleotides were ligated to $0.5 \mu \mathrm{g}$ of genomic DNA. In a second step, $100 \mathrm{ng}$ of the ligation reaction were $\mathrm{PCR}$-amplified for 23 cycles $\left(94^{\circ} \mathrm{C} / 1 \mathrm{~min}\right.$, $72{ }^{\circ} \mathrm{C} / 3 \mathrm{~min}$, with a final $72{ }^{\circ} \mathrm{C} / 5$ min extension) using Advantage cDNA polymerase mix (Clontech). Of each PCR reaction $10 \mu \mathrm{l}$ were analysed on $1.8 \%$ agarose-TBE gels in presence of ethidium bromide, at $60 \mathrm{~mA}$ for $4 \mathrm{~h}$. With this technique nucleosome fragments, whose length varies by multiples of 180 to 200 base pairs, can be visualized, allowing the DNA ladder to be easily observed.

Analysis of Apoptotic nuclei by Fluorescent Activated Cell Sorting (FACS). Apoptotic cell nuclei were detected in $\beta$ TC6F7 cells treated with anti-NGF antibody 6,12 or 24 treatment in serum free conditions by flow cytometry as described [50] with slight modifications by others [51]. Briefly, cells were harvested, centrifuged at $200 \mathrm{~g}$ for $10 \mathrm{~min}$ and washed twice with PBS. Then they were gently resuspended in $1 \mathrm{ml}$ propidium iodine hypotonic solution $(50 \mathrm{\mu g} / \mathrm{ml}$ in $0.1 \%$ sodium citrate added in $0.1 \%$ Triton-X 100) and incubated at $4^{\circ} \mathrm{C}$ for $40 \mathrm{~min}$ in darkness. The fluorescence emitted from PI-DNA complex was quantified after laser excitation (488 nm) using a FACScan (Becton Dickinson, Milan, Italy).

Experiments were carried out on about $10^{4}$ cells and repeated three to five times.

Statistical analysis. Data are given as the average \pm SEM. Statistical analysis was carried out by one-way ANOVA followed by Student's $t$ test. A $p$ value of less than 0.05 was considered statistically significant.

\section{Results}

NGF, gp140 Trk-A and p75 ${ }^{\text {NTR }}$ mRNAs expressed in BTC6-F7 cells, human islets and dissociated human beta cells. We show that for NGF and its receptors gp $140^{\text {Trk-A }}$ and $\mathrm{p} 75^{\mathrm{NTR}}$, mRNAs are expressed in $\beta$ TC6-F7 cells after 40 cycles of amplification (Fig. 1A).

We illustrate NGF, gp $140^{\text {Trk-A }}$ and $\mathrm{p} 75^{\text {NTR }}$ mRNAs expression in human islets and in human purified beta cells (Fig. 1B-C). NGF mRNA was RT-PCR amplified for 40 cycles whereas gp $140^{\text {Trk-A }}$ and $\mathrm{p} 75^{\mathrm{NTR}}$ mRNAs were amplified for 55 cycles, suggesting that NGF receptors mRNA, in particular gp140 ${ }^{\text {Trk-A }}$, are expressed relatively low compared with NGF.

In control experiments (where MMLV was omitted during the reverse transcription reaction), no PCR signal could be detected even after 60 cycles (data not shown).

p75 ${ }^{N T R}$ and gp140 ${ }^{\text {Trk-A }}$ proteins expressed in $\beta$ TC6-F7 cells and in human islets: western blot analysis. Western blot analyses were done in $\beta$ TC6-F7 cells to vali-
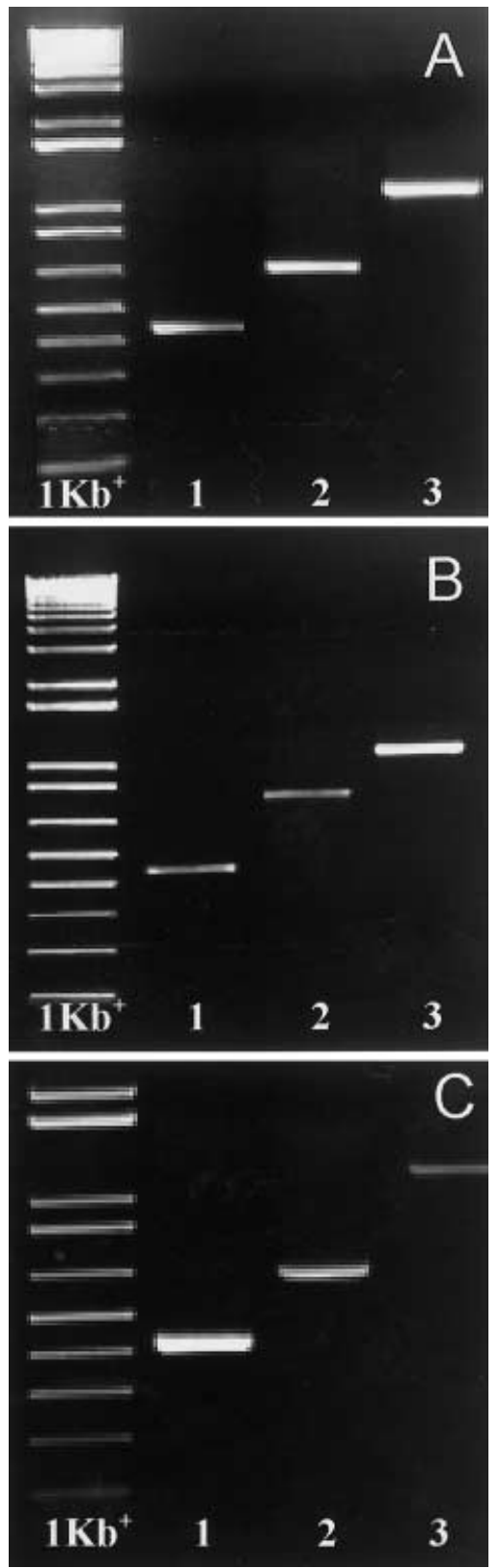

Fig. 1. RT-PCR analysis of NGF, gp $140^{\text {Trk-A }}$ and $\mathrm{p} 75^{\mathrm{NTR}}$ in $\beta$ TC6-F7 (A), in adult human islets (B) and in purified human beta cells $(\mathbf{C})$. Representative RT-PCR analysis of NGF (lane 1), gp $140^{\text {Trk-A }}$ (lane 2) and p75 ${ }^{\text {NTR }}$ (lane 3). RT-PCR was carried out as described in the method section and repeated three times. PCR products were analysed after 40 cycles in $\beta$ TC6-F7 for all three messengers. For human material, NGF was amplified for 40 cycles and NGF receptors required 55 cycles. Standard MW marker on the left size of the gel was a $1 \mathrm{~Kb}^{+} \mathrm{DNA}$ ladder (Gibco)

date the specificity of gp $140^{\text {Trk-A }}$ and $\mathrm{p} 75^{\mathrm{NTR}}$ antibodies. We found that gp140 Trk-A and $\mathrm{p} 75^{\mathrm{NTR}}$ antibodies labelled blots as a single band with a molecular weight of $140000 \mathrm{M}_{\mathrm{r}}$ for $\mathrm{gp} 140^{\text {Trk-A }}$ and as single band of about $75000 \mathrm{M}_{\mathrm{r}}$ for $\mathrm{p} 75^{\mathrm{NTR}}$ corresponding with the expected molecular weight (Fig.2). NGF protein expression was not detectable by this method (data not shown). 


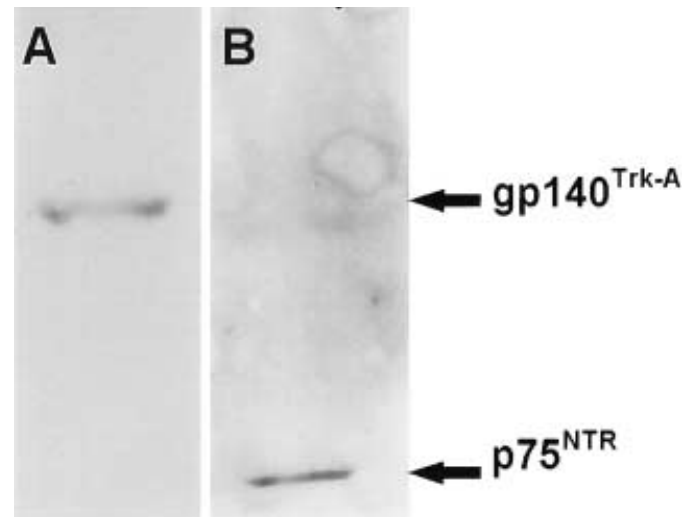

Fig. 2. Western blot analysis of gp $140^{\text {Trk-A }}$ and $\mathrm{p} 75^{\mathrm{NTR}}$ NGF receptors in $\beta$ TC6-F7 Western blot for gp140 ${ }^{\text {Trk-A }}(\mathbf{A})$ and $\mathrm{p} 75^{\mathrm{NTR}}$ (B) was set up as described in the method section. For each antibody used, a single band was observed: lane A: gp140 Trk-A $\left(140000 \mathrm{M}_{\mathrm{r}}\right)$, lane B: p75 ${ }^{\mathrm{NTR}}\left(75000 \mathrm{M}_{\mathrm{r}}\right)$

Immunofluorescence analysis. Figure 3 shows results from dual immunolabelling experiments in $\beta$ TC6-F7 cells (A-F) and in human islets primary cultures (G-L). For all secondary antibodies used, the background measured omitting the primary antibody during the immunoprocessing was almost undetectable. Therefore, at the concentrations of the secondary antibodies used, the signals obtained in primary antibody was specific (data not shown).

We revealed gp $140^{\text {Trk-A }}$ and p75 ${ }^{\text {NTR }}$ (Fig. 3B,D) using FITC-conjugated secondary antibodies in $\beta$ TC6F7 cells where insulin-like immunoreactivity was evidenced by TRITC-conjugated secondary antibodies (Fig. 3A, C). The two NGF receptor types co-localized in the same cells (Fig. 3 E, F) where PE labelled cells are immunoreactive for gp140 ${ }^{\text {Trk-A }}$, and FITC labelled cells are immunoreactive for $\mathrm{p} 75^{\mathrm{NTR}}$. The insulin-like immunoreactivity could be clearly evidenced because numerous cytoplasmic "vesicle-like" structures are labelled (Fig. 3A, C). Other than gp140 Trk-A and $\mathrm{p} 75^{\mathrm{NTR}}$ immunoreactivity was widespread with some "vesicle-like" structures particularly evident for gp140 Trk-A (Fig. 3B,3E).

In a second set of experiments dual immunolabelling was done on human islets. Colocalization of insulin (Fig. 3H,I) with gp140 1 Trk-A $($ Fig. $3 \mathrm{G})$ or with $\mathrm{p} 75^{\mathrm{NTR}}$ (Fig. 3J) as well as co-localization for both receptor types was analysed (Panels $\mathrm{K}$ for gp140 ${ }^{\text {Trk-A }}$ and L for $\mathrm{p} 75^{\mathrm{NTR}}$ ). Insulin-like immunoreactive cells were also immunoreactive for gp140 ${ }^{\text {Trk-A }}$ (Fig. $3 \mathrm{G}-\mathrm{H}$ ) but some gp $140^{\text {Trk-A }}$ positive cells were also identified as non-beta-cells (Arrow in Fig.3G). Also, while virtually all of the beta cells analysed were $\mathrm{p} 75^{\mathrm{NTR}}$ positive (Fig. 3I, J), we also found some p75 ${ }^{\mathrm{NTR}}$ immunoreactive cells negative for insulin-like immunoreactivity (Arrow in Fig. 3J). Therefore beta cells exhibit both NGF receptor types as well as other non-beta islets cells. Dual immunolabelling gp $140^{\text {Trk-A }} / \mathrm{p} 75^{\text {NTR }}$
(Fig. 3K, L) showed at least two other cell populations, the first $\mathrm{p} 75^{\mathrm{NTR}}$ but not gp $140^{\text {Trk-A }}$ was immunoreactive (see arrow in panel $\mathrm{K}$ ) and the second was gp $140^{\text {Trk-A }}$ and $\mathrm{p} 75^{\text {NTR }}$ immunoreactive.

NGF synthesized and released from $\beta T C 6-F 7$ cells. Autoradiography of newly synthesized proteins in $\beta$ TC6-F7 cells after immunoprecipitation with an anti-NGF antibody was done in the culture medium and cell extracts, showing a single band of $14000 \mathrm{M}_{\mathrm{r}}$ (Fig. 4) in the culture medium but not in cell extracts.

Biologically active NGF produced by $\beta$ TC6-F7 cells. PC12 cells treated with exogenous NGF started to expand neurites within 48 to $72 \mathrm{~h}$ and a neurite outgrowth was clearly visible after 5 days (Fig. 5B) while untreated $\mathrm{PC} 12$ cells remained undifferentiated (Fig. 5A). PC12 cells co-cultured with $\beta$ TC6-F7 cells show similar neurite-like outgrowth, though with a slower progression (Fig. 5C).

Basal PS translocation (T0, FITC labelling) was barely detectable in human islets and in bTC6-F7 cells (Fig. 6). In human islets, after anti-NGF treatment, PS translocation started within $30 \mathrm{~min}$ in more than $90 \%$ of insulin-like immunoreactive cells and was still increased after $2 \mathrm{~h}$. Similar results were observed in bTC6-F7 cells. Annexin-V staining pattern in human cells appeared more clustered than that observed in the insulinoma cell line; this is probably due to the fixation step required after annexin- $\mathrm{V}$ binding for insulin immunolabelling.

Nucleosomal formation assay after anti-NGF treatment. The enrichment factor in cells grown in serum free medium compared with cells grown in complete

Fig. 3 A-L. Immunofluorescent microscopy analysis of Insulin, p $^{\text {NTR }}$ and gp140 ${ }^{\text {Trk-A }}$ NGF receptors in $\beta$ TC6-F7 (A-F) and in Human islets cultures $(\mathbf{G}-\mathbf{L})$. Dual immunolabelling analysis for insulin and gp140 ${ }^{\text {Trk-A }}$ in $\beta$ TC6-F7 (A-B) and in human islets preparation $(\mathbf{H}-\mathbf{G})$. Immunoreactive vesicles clearly evidence insulin vesicles in $\beta$ TC6-F7 (A) as in human islets $(\mathbf{H})$. gp140 ${ }^{\text {Trk-A }}$ also shows a punctuate pattern that should correspond to receptor patches and evidences cytoplasmic membranes $(\mathbf{B}, \mathbf{G})$. Note that, while virtually all $\beta$ TC6-F7 are immunoreactive for insulin and gp $140^{\text {Trk-A }}$, in human islets some gp140 Trk-A positive cells are not insulin-like immunoreactive (arrow in $\mathbf{G})$. In $\mathbf{C}$ to $\mathbf{D}$ ( $\beta$ TC6-F7) and $\mathbf{I}$ to $\mathbf{J}$ (human islets) preparations were dually labelled for insulin and $\mathrm{p} 75^{\mathrm{NTR}}$ : still all $\beta$ TC6-F7 are immunoreactive for insulin and $\mathrm{p} 75^{\mathrm{NTR}}$ but, in human islets, numerous $\mathrm{p} 75^{\mathrm{NTR}}$ immunoreactive cells where found to be non-beta-cells (insulin-like immunoreactivity negative; arrow in $\mathbf{J})$. In $\mathbf{E}$ to $\mathbf{F}$ ( $\beta$ TC6-F7) and $\mathbf{K}$ to $\mathbf{L}$ (human islets) preparations were dually labelled for gp140 Trk-A and $\mathrm{p} 75^{\mathrm{NTR}}$. $\beta$ TC6-F7 exhibit both receptors types whereas in human preparations, as for cell evidenced by the arrow in panel $\mathrm{K}$, some $\mathrm{p} 75^{\mathrm{NTR}}$ immunolabelled cells were negative for gp140 Trk-A whereas all gp140 ${ }^{\text {Trk-A }}$ immunolabelled cells $(\mathbf{L})$

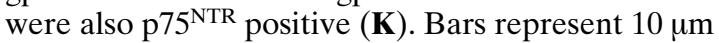




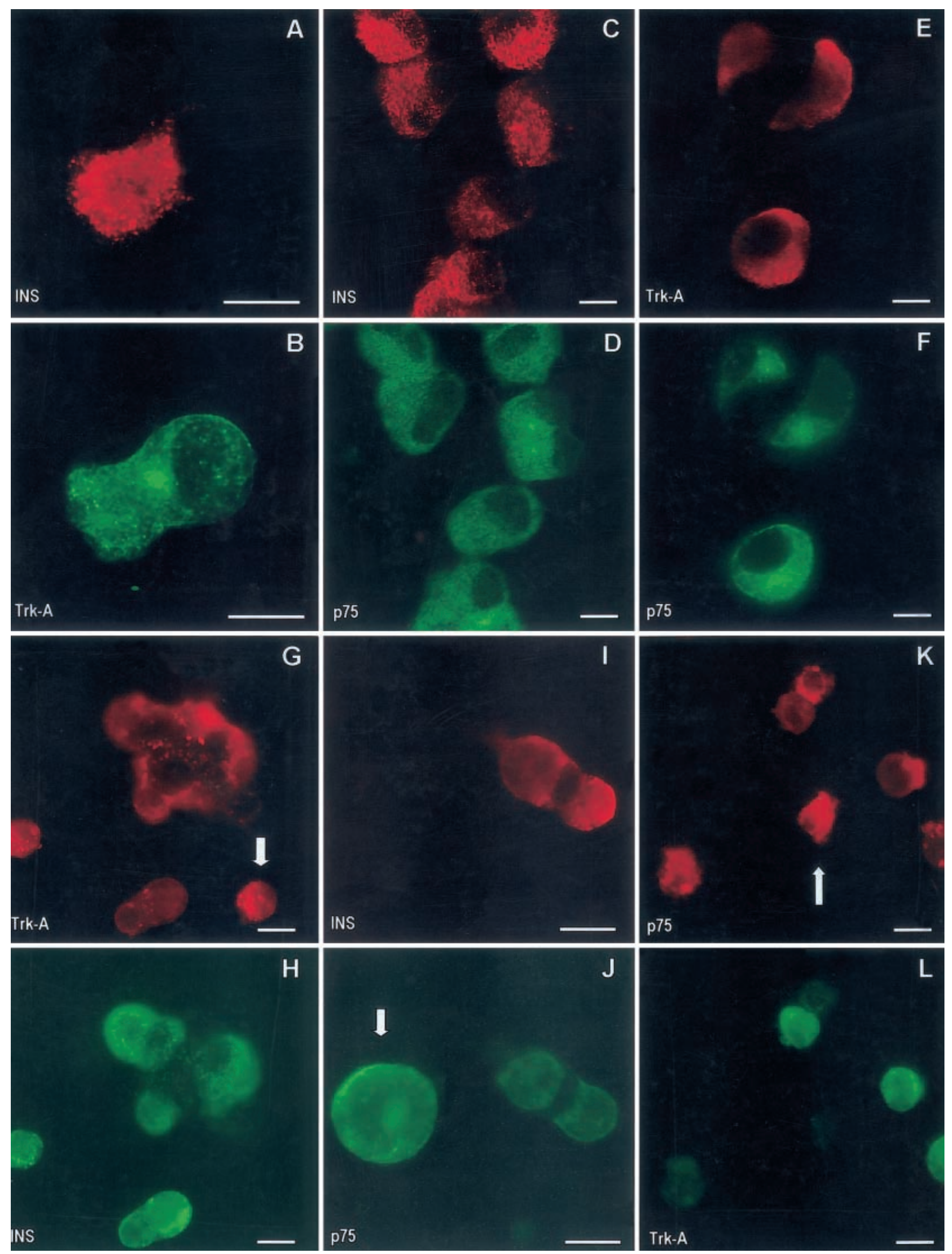




\section{Cell Extract Medium}

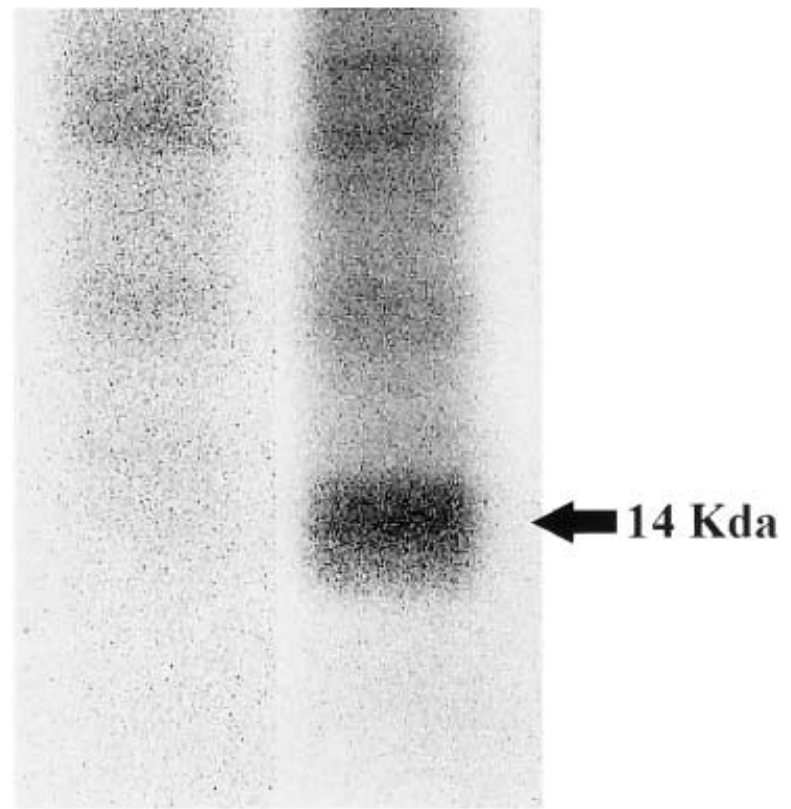

Fig.4. Biosynthetic labelling of proteins in $\beta$ TC6-F7 ${ }^{35} \mathrm{~S}-\mathrm{la}-$ belled proteins contained in cell extract or culture medium were immunoprecipitated with an anti-NGF antibody conjugated to protein-A sepharose, separated onto PAGE-SDS and revealed by autoradiography (see methods). The 14000 $\mathrm{M}_{\mathrm{r}}$ arrow points to a band tentatively identified as NGF

medium was $1.07 \pm 0.09$ after $6 \mathrm{~h}$, indicating that serum withdrawal did not induce nucleosome enrichment (Fig. 7). On the contrary, after 12 and $24 \mathrm{~h}$ serum withdrawal, nucleosomal enrichment factor was increased by $1.59 \pm 0.21$ ( $p<0.05$ vs control cultures) and $1.96 \pm 0.22$ ( $p<0.01$ vs control cultures).

Cells treated with anti-NGF antibody showed an increase in nucleosome formation after $6 \mathrm{~h}$ compared with control cells $(2.08 \pm 0.20)$; this increase was significant even when compared with cells maintained in serum-free condition ( $p<0.01$ vs serumfree cultures). After $12 \mathrm{~h}$, enrichment factor did not change significantly $(1.93 \pm 0.13, p<0.05$ vs serumfree cultures) whereas after $24 \mathrm{~h}$, it markedly increased up to $3.30 \pm 0.45$ ( $p<0.01$ vs serum-free cultures).

Analysis of DNA laddering. Representative gel electrophoresis images of DNA laddering analysis are shown in Figure 8. Cells grown in complete medium did not show DNA laddering (data not shown). After $6 \mathrm{~h}$, DNA laddering was barely visible in control and in anti-NGF treated cells. A slight DNA laddering started to appear in control cells after $12 \mathrm{~h}$ and was evident after $24 \mathrm{~h}$. In contrast, a severe DNA laddering was already evident after $12 \mathrm{~h}$ in antiNGF treated cells and was even more pronounced after $24 \mathrm{~h}$.

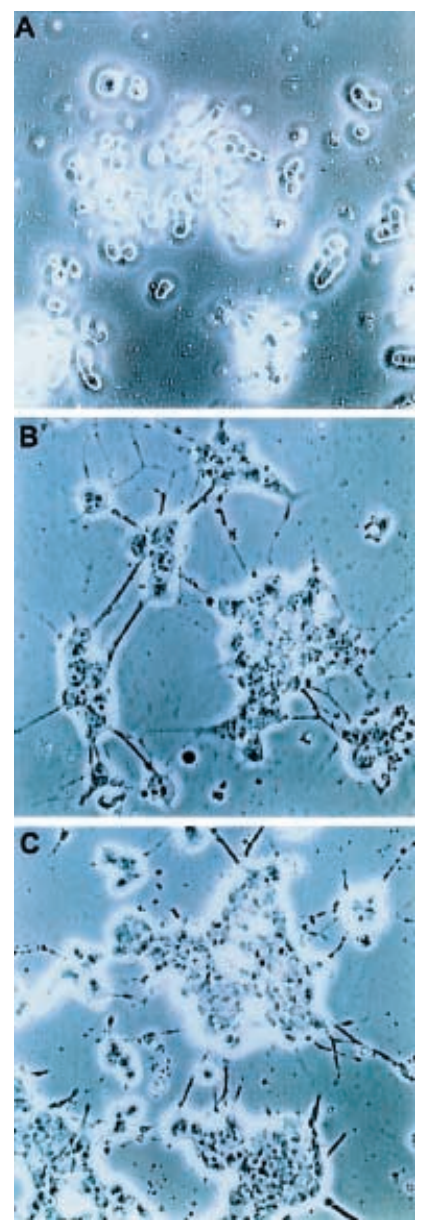

Fig.5. $\beta$ TC6-F7 conditioned medium induces neurite outgrowth in PC12 like exogenous NGF. PC12 cells were grown as described in Methods and observed after 5 days in vitro (A). In B, PC12 were treated with NGF $(100 \mathrm{ng} / \mathrm{ml}$ daily for 5 days) while in $\mathbf{C}, \mathrm{PC} 12$ were exposed to $\beta$ TC6-F7 conditioned medium for 5 days. Neurites expanding from PC12 can be seen in both NGF treated (B) and conditioned medium exposition $(\mathbf{C})$ conditions, showing that $\beta$ TC6-F7 cells produce and release a biologically active form of NGF

Analysis of apoptotic nuclei by fluorescent activated cell sorting (FACS). Analysis by single-fluorescence flow cytometry FL-2 diagrams of nuclei from $\beta$ TC6F7 cells cultured in serum-free medium in the absence (control cells) or in the presence (treated cells) of anti-NGF antibody is reported in Table 1.

This indicates the per cent of apoptotic nuclei in control or treated cells. The first column shows the percentage relative to untreated cells in standard culture conditions. After $6 \mathrm{~h}$ the percentage of apoptotic cells was similar in untreated cells maintained in standard culture condition and in control cells in serumfree culture condition. After $12 \mathrm{~h}$ and $24 \mathrm{~h}$ the percentage of apoptotic cells did not change in cells in standard culture conditions, whereas it increased in a time-dependent manner in cells in serum-free condition. The percentage of apoptotic cells was significantly increased in a time-dependent manner in treat- 

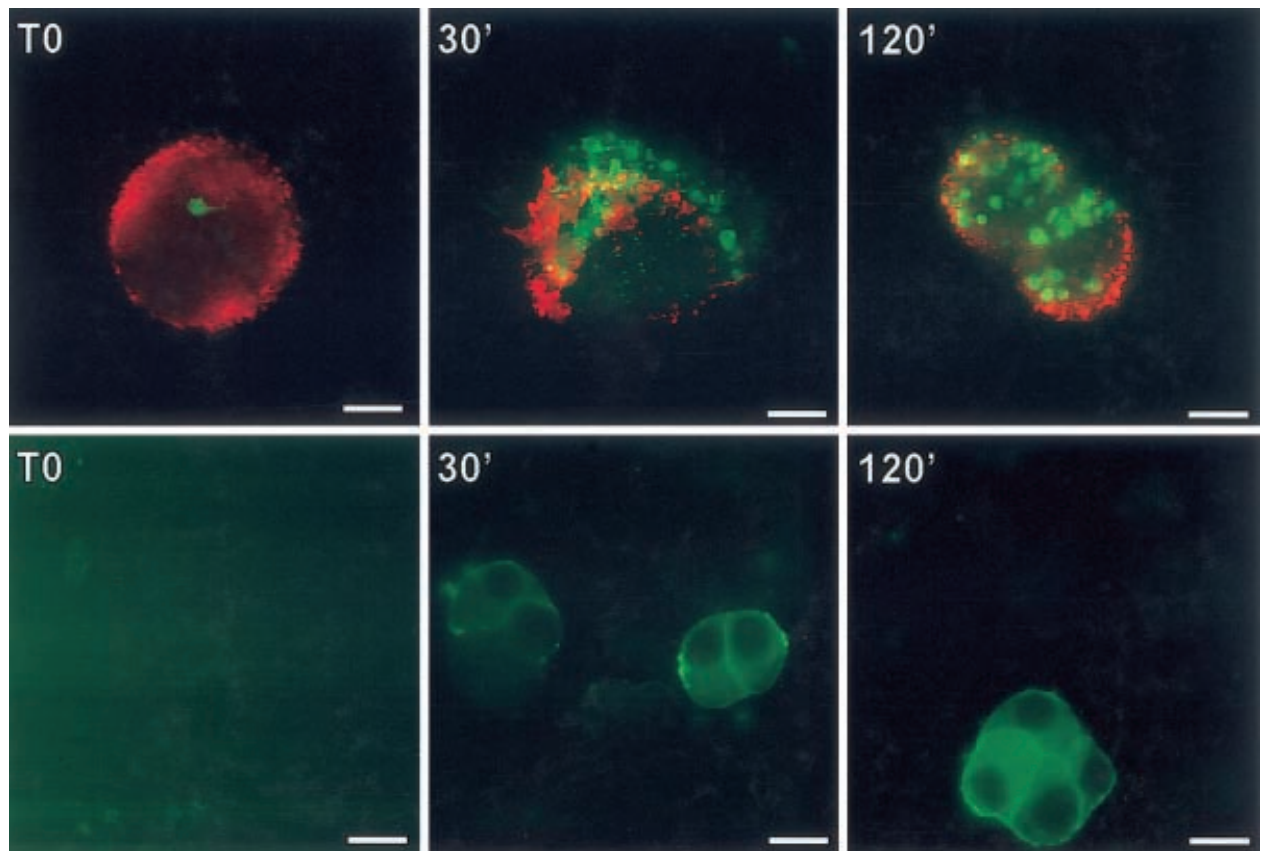

Fig. 6. Phosphatidylserine translocation was monitored by annexin-V FITC conjugated binding after NGF treatment for 30 or $120 \mathrm{~min}$ in human islets (upper panel) and in $\beta$ TC6-F7 cells (lower panel). For human cells, beta-cell phenotype which represents about $60-70 \%$ of total cells was revealed by anti-insulin antibody (TRITC fluorescence) after annexin VFITC binding (see methods). More than $90 \%$ of insulin-positive cells exhibited annexin V-FITC binding after anti-NGF treatment. For $\beta$ TC6-F7 cells, virtually all cells exhibited annexin V-FITC binding after anti-NGF treatment. Control cultures (T0), in absence of anti-NGF antibody $(10 \mu \mathrm{g} / \mathrm{ml})$, were also prepared to measure the basal phosphatidylserine (PS) translocation. Bars represent $5 \mu \mathrm{m}$ for human cells and $10 \mu \mathrm{m}$ for $\beta \mathrm{TC6}-\mathrm{F} 7$

ed cells, compared with control or untreated cells (Table 1).

Nucleosomal formation assay after AG879 treatment. Involvement of gp140 ${ }^{\text {Trk-A }}$ receptor in NGF action was evaluated by treating $\beta$ TC6-F7 cells with Tyrphostin AG879; nucleosomal formation assay (three independent experiments) showed that AG879 induced an increase in nucleosome enrichment after $24 \mathrm{~h}$ $(2.58 \pm 0.27, p<0.05$ vs control) which is comparable to the increase obtained with anti-NGF antibody treatment $(2.83 \pm 0.35)$. In contrast, A1 tyrphostin treatment had no significant effect $(1.15 \pm 0.15$, $p<0.01)$.

Nucleosomal formation assay after AMD or CHX treatments. AMD or CHX treatments did not induce nucleosomal formation in $\beta$ TC6-F7 cells (enrichment factor was $0.96 \pm 0.02$ and $0.98 \pm 0.04$, from four independent experiments). Pretreatment with AMD or with $\mathrm{CHX}$ did not prevent beta cell apoptosis in

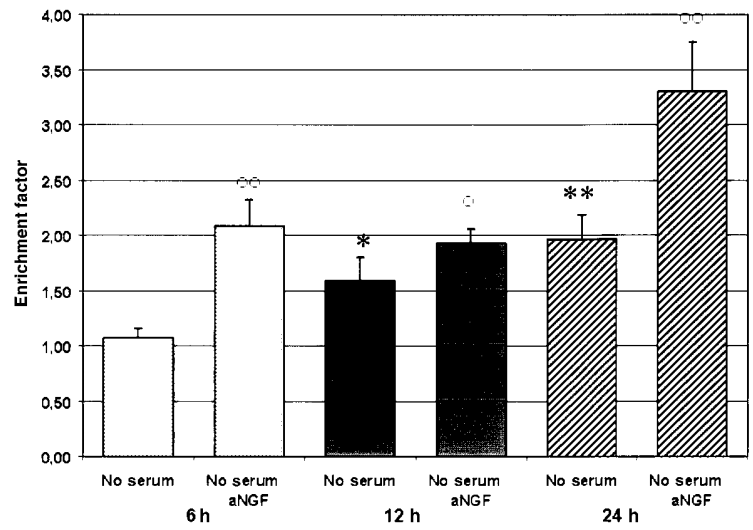

Fig. 7. Nucleosomal formation was evidenced in $\beta$ TC6-F7 as described in the method section after 6,12 or $24 \mathrm{~h}$ of NGF withdrawal. Results are expressed as "percent enrichment factor" in anti-NGF treated cultures (see methods), showing increased nucleosomal formation in anti-NGF-treated cells. Enrichment factor in control group is 1 . Each measurement is the mean of three culture dishes and the experiment was repeated five times; ${ }^{\circ}$ and ${ }^{\circ}$ respectively $p<0.05$ and $p<0.01$ vs no serum treated cells; $*$ and $* *$ respectively $p<0.05$ and $p<0.01$ vs control cells cultured in complete medium

anti-NGF antibody-treated cells (enrichment factor was $1.41 \pm 0.10$ and $1.79 \pm 0.30$ vs $1.63 \pm 0.25$ in antiNGF treated cells).

NGF withdrawal decreases AKT and Bad phosphorylation. Western blot analyses on anti-phospho (Ser473) AKT or anti total AKT antibody are shown in Figure 9B. Total content of AKT did not change throughout the experiment. On the contrary, Ser-473 phosphorylated fraction was severely reduced after 30 min of anti-NGF treatment $(0.18 \pm 0.05$ fold basal content) compared with serum-free maintained con- 

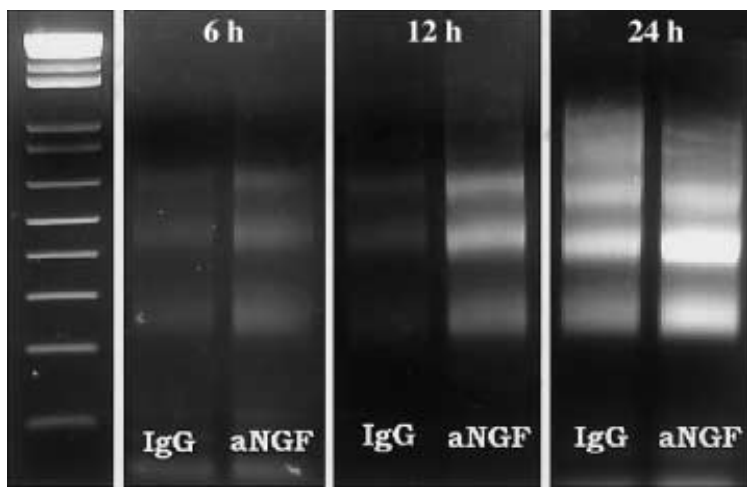

Fig. 8. DNA laddering in $\beta$ TC6-F7 cells exposed to NGF deprivation (see methods) for 6,12 or 24 h showing nucleosomal bands intense staining in anti-NGF treated cells. $\alpha-N G F$ : antiNGF treated cultures, IgG, immunoglobulin treated cultures (control). Left lane is a $1 \mathrm{~Kb}^{+}$DNA ladder (Gibco)

Table 1. FACS analysis of apoptotic $\beta$ TC6-F7 cells after NGF withdrawal

\begin{tabular}{rlrl}
\hline & Control & No serum & $\begin{array}{l}\text { No serum } \\
+\alpha \text {-NGF }\end{array}$ \\
\hline 6 hours & $10.86 \pm 1.66$ & $9.78 \pm 0.69$ & $24.70 \pm 5.16^{*}$ \\
12 hours & $11.61 \pm 0.48$ & $12.30 \pm 1.64$ & $20.60 \pm 1.51^{*}$ \\
24 hours & $11.34 \pm 2.41$ & $20.13 \pm 4.83$ & $46.72 \pm 4.28^{* *}$ \\
\hline
\end{tabular}

Per cent (means \pm SEM) of $\beta$ TC6-F7 apoptotic cells after 6,12 and $24 \mathrm{~h}$ in control, serum-free maintained and anti-NGF treated cultures as measured by FACS analysis. Means and SEM are obtained from three independent experiments. $* p<0.05$ vs control, **. $p<0.01$ vs control

trol cultures $(0.67 \pm 0.10$-fold basal content $)$. After $1 \mathrm{~h}$, the phosphorylated fraction of AKT was also lowered in control cultures and later on it remained low in both experimental conditions.

Conversely, the same analysis on phospho-Bad and total Bad (Fig.9B) shows that the phosphorylated fraction of Bad (Ser-136) was significantly decreased within 3 to $6 \mathrm{~h}$ of anti-NGF treatment (anti-NGF: $0.50 \pm 0.10$ vs control: $1.14 \pm 0.09$-fold basal content, $p<0.05)$. With AKT, serum withdrawal did not significantly reduce the Ser-136 phosphorylated fraction of Bad, even $3 \mathrm{~h}$ after the anti-NGF treatment.

NGF withdrawal transiently increases ERKs phosphorylation. ERKs (p42 and p44) phosphorylation was transiently increased one hour after NGF-withdrawal (anti-NGF: $1.93 \pm 0.28$ vs control: $1.14 \pm 0.09$, $p<0.05$, Fig. 9C). Successively, no significant differences persisted between the two experimental conditions.

The total content of ERKs were not affected throughout the experiment.

NGF withdrawal enhances JNK but not p38 MAPK activities. p38 MAPK and JNK activities are repre- sented in Figure 9D and E. Whereas NGF withdrawal did not seem to significantly modulate p38 MAPK activity, JNK activity was severely increased in antiNGF compared with control cultures which were maintained serum-free. Moreover, the dynamic of this event was very fast since JNK activity was increased almost ten times within 15 min (anti-NGF: $9.04 \pm 1.61$ vs control: $1.22 \pm 0.10$-fold basal content) and reaching almost 20 times after 30 min (antiNGF: $18.92 \pm 2.37$ vs control: $1.56 \pm 0.05$-fold basal content, $p<0.05$ ). After one hour of anti-NGF treatment, JNK activity was also increased in control culture conditions but remained higher in anti-NGF antibody (anti-NGF: $15.32 \pm 2.25$ vs control: $10.24 \pm 2.61$-fold basal content).

$N G F$ withdrawal decreases $B c l-X_{L}$ but not Bcl-2 content. Two representative blots for $\mathrm{Bcl}-2$ and $\mathrm{Bcl}-\mathrm{X}_{\mathrm{L}}$ as well as a densitometric analysis of proteins expression are shown in Figure 9F. Results are expressed as "fold protein expression in anti-NGF treated cells vs no serum controls". Whereas Bcl-2, whose expression appeared lower than $\mathrm{Bcl}-\mathrm{X}_{\mathrm{L}}$, was not significantly altered up to $12 \mathrm{~h}$ after anti-NGF treatment, $\mathrm{Bcl}-\mathrm{X}_{\mathrm{L}}$ expression was severely reduced (more than $50 \%$ ) after $3 \mathrm{~h}$ in anti-NGF treated cells compared with serum free control cultures. Of interest, in serum-free control cells $\mathrm{Bcl}-\mathrm{X}_{\mathrm{L}}$ appeared increased throughout the experiment compared with basal content (T0).

\section{Discussion}

NGF mRNA and protein expression have been observed in rat islets but the cell type expressing the neurotrophin has not been characterized $[16,52,53]$. A recent study showed that rat beta cells produce NGF [54] whereas previous reports failed to demonstrate NGF mRNA and/or receptor expression $[17-19,55]$. To clarify this issue, we characterized the expression of NGF and its receptors, gp $140^{\text {Trk-A }}$ and $\mathrm{p} 75^{\mathrm{NTR}}$, in $\beta \mathrm{TC} 6-\mathrm{F} 7$ cells, human islets and human purified beta cells.

We have shown that NGF mRNA is highly expressed in $\beta$ TC6-F7 cells compared with other insulinoma cell lines (i.e. RIN 1046-38 and INS-1 cells, data not shown). We have also shown the expression of NGF mRNA in human islets particularly in beta cells where it seems to be abundant. Although mRNA from contaminating material in the RT-PCR experiments cannot be excluded, the possibility that NGF mRNA expression in human islets derives from peri-islet cell contamination can be ruled out because Schwann cells do not survive in these culture conditions. At most, NGF mRNA could be produced by the fibroblasts surrounding the islets [16] though the neurotrophin expression by these cells has yet to be found. 


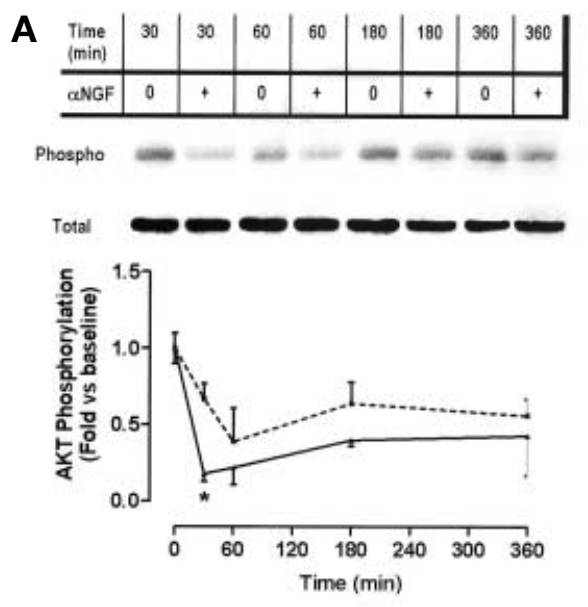

B \begin{tabular}{l|c|c|c|c|c|c|}
$\begin{array}{c}\text { Time } \\
\text { (min) }\end{array}$ & 60 & 60 & 180 & 180 & 360 & 360 \\
\hline aNGF & 0 & + & 0 & + & 0 & + \\
\hline
\end{tabular}
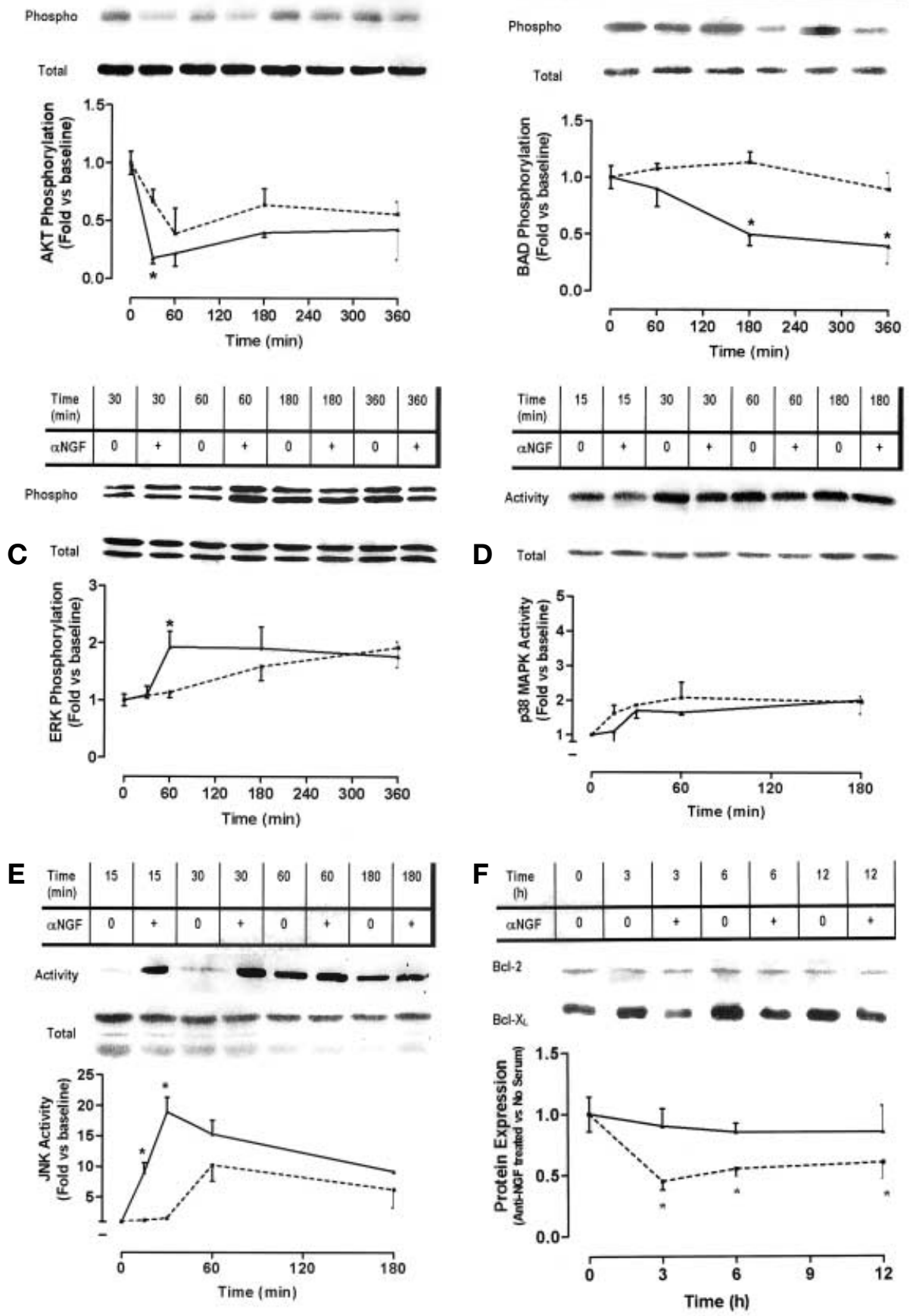

Fig.9 A-F. Quantitative analysis after NGF withdrawal in $\beta$ TC6-F7 of total and phosphorylated fractions (Ser-473) AKT (A), (Ser-136) Bad (B), ERKs (p42 and p44, C), and for p38MAPK activity (D) and JNK activity (E). Data $(n=5$ for AKT, $n=3$ for BAD, $n=3$ for ERK, $n=5$ for p38 and JNK) are plotted as "fold phosphorylation" for AKT, BAD and ERK or as "fold increase" for p38 or JNK activities vs basal content. Times are indicated on the $x$ axis in anti-NGF antibody (plain line) or not (dashed line). Panel $\mathbf{F}$ is a quantitative analysis of western blot for $\mathrm{Bcl}-2$ and $\mathrm{Bcl}-\mathrm{X}_{\mathrm{L}}$ protein expression after NGF withdrawal in $\beta$ TC6-F7 $(n=3$ for each protein). ${ }^{*} p<0.05$ vs no serum treated control cells

We failed to demonstrate the expression of NGF in $\beta$ TC6-F7 cells and human islets by different techniques [western blot, immunofluorescence or ELISA, both in cell extracts and in culture medium (data not shown)]; this is probably due to the small amount of neurotrophin and its rapid turn over and/or secretion. In contrast, autoradiography with immunoprecipitation of newly synthesized proteins showed the presence of NGF in the culture medium of $\beta$ TC6-F7 cells but it was not detected in the cell extracts. These results suggest that NGF is synthesized in beta cells 
and rapidly released, in agreement with previous data [54]. The endogenously produced NGF is biologically active since $\beta$ TC6-F7 co-cultured with PC12 cells induced PC12 neurite outgrowth. Although a local effect of NGF produced and released by beta cells seems to be suggestive, the effect of other factor(s) could be involved.

Our data show the concomitant expression of NGF and its receptors in islets beta cells in vitro and the synthesis and release of biologically active NGF from beta cells, suggesting the existence of an autocrine loop.

Although there is evidence indicating a role for NGF in the development and maturation of the pancreas, its action in adults is not clear [14,16,56-58]. Also, the role of $\mathrm{p} 75^{\mathrm{NTR}}$ on beta cells is intriguing. Indeed, $\mathrm{p} 75^{\mathrm{NTR}}$ has been considered to be involved in the modulation of apoptosis and/or survival in neurons [59-67]. The same mechanism has been shown to operate in B lymphocytes [43] and in fibroblasts [68], keratinocytes or PC12 cells where NGF withdrawal induces apoptosis [22,69-73].

Based on this evidence, we hypothesized that NGF could be involved in modulating islet beta cells apoptosis and/or survival. To this aim we have shown that NGF withdrawal induces phosphatidylserine (PS) translocation on the surface of human beta cells, affecting almost only insulin immunoreactive cells. This is, to our knowledge, the first demonstration that NGF is an important factor for the survival of human beta cells.

Because of difficulties in obtaining human islets, we have used the well characterized $\beta$ TC6-F7 cell line as an experimental model to show that NGFwithdrawal induces apoptosis in beta cells[39,74].

NGF-withdrawal-induced apoptosis seems to be mediated through gp140 ${ }^{\text {Trk-A }}$ since Tyrphostin AG879 could mimic the effect of NGF immunodeprivation. The presence of NGF is therefore necessary for gp $140^{\text {Trk-A }}$ phosphorylation and beta-cell survival.

This apoptotic mechanism does not require gene expression nor de novo synthesis of protein as shown by actinomycin-D and cycloheximide experiments differing from NGF-withdrawal-induced apoptosis in neurons [77,78]. It is therefore possible that the signal transduction pathway used by beta cells for NGFwithdrawal-induced apoptosis differs from that used by neurons. Furthermore, the time-course of cell death differs in neurons and beta cells. Whereas apoptosis in neurons occurs after 12 to $24 \mathrm{~h}$, in beta cells the event is more rapid, supporting the hypothesis that the process does not involve gene expression.

Analysis of the signal transduction pathways involved supported such "transcription/translation independent mechanism". Indeed, we could evidence that JNK is severely activated within 15 min of antiNGF treatment. However, p38 MAPK activity did not change after NGF withdrawal and the ERK's phosphorylation appeared very blind though it was statistically significant. In tandem, we could measure a dephosphorylation of AKT after $30 \mathrm{~min}$ and successively a dephosphorylation of Bad in position Ser136.

In our system, whereas AKT was also found dephosphorylated in position Ser-473 by serum withdrawal, Bad dephosphorylation in position Ser-136 was only found after NGF withdrawal while serum withdrawal per se was not affected. This suggests that BAD Ser-136 could also be phosphorylated by kinase(s) other than AKT. PAK-1 (p21-activated kinase 1 ) is a possible candidate [79]. We also analysed the PI3-K activity after $6 \mathrm{~h}$ of anti-NGF treatment and found it severely decreased; the PI3-K activity could be restored by treatment of the cells with 100 $\mathrm{ng} / \mathrm{ml}$ NGF for $15 \mathrm{~min}$ (data not shown).

Activation of PI3-K by NGF has been reported in PC12 cells [80] and the PI3-K/Akt proteins seem necessary and sufficient for the survival of NGF-dependent sympathetic neurons [81]. We show that in beta cells maintained in vitro, serum withdrawal reduces the kinase activity of PI3-K and AKT as NGF does but that serum withdrawal does not influence the phosphorylation status of Bad in position Ser-136; on the contrary NGF withdrawal dephosphorylates Bad in position Ser-136. Therefore the participation of other kinases (i.e. PAK-1) in this pathway cannot be excluded. Nevertheless, it has been shown that Ser136 phosphorylation leads to subsequent Ser-155 phosphorylation and that it is therefore crucial for Bad to bind cytosolic 14-3-3 proteins remaining inactive. In contrast, dephosphorylated $\mathrm{Bad}$ is able to bind $\mathrm{Bcl}-\mathrm{X}_{\mathrm{L}}$ eliciting its pro-apoptotic effect [82]. Thus, the inhibition of the PI3-K/AKT/BAD "survival" pathway, appears as a consequence of NGF withdrawal and could justify, at least in part, apoptosis of the cells.

JNK was activated by $1 \mathrm{~h}$ serum withdrawal but this activation was lower than that measured after NGF withdrawal which occurs within minutes. P38 MAPK activity remained unchanged in both experimental conditions. JNK, and not p38 MAPK, was shown to be activated by NGF withdrawal in sympathetic neurons, as we have shown in beta cells [83] while, in CESS B cell line, NGF withdrawal induces a p38 MAPK and not a JNK activation [25]. Also, in cultured cerebellar granule neurons, inhibition of PI3-K activated JNK activity [84]. Thus, the activation of JNK after NGF withdrawal seems to be associated with the inhibition of the PI3-K-AKT-BAD survival pathway and the activation of JNK pathway. Indeed, the involvement of the JNK pathway in IL1 $\beta$ induced beta-cell apoptosis has been shown using a bioactive cell-permeable peptide inhibitor of JNK which gives full protection against IL1 $\beta$ induced apoptosis in insulinoma $\beta \mathrm{TC}_{3}$ cells for up to two weeks of continuous treatment with the cytokine. 
Therefore JNK activation is a key event in this process [85].

Though the cellular Bcl-2 contents did not change, Bcl-XL showing increased expression by serum withdrawal, was severely decreased by NGF withdrawal. Together, these mechanisms support the nucleosomal formation increase we measured $6 \mathrm{~h}$ after NGF withdrawal and the subsequent DNA laddering measured by FACS analysis and DNA laddering gel electophoresis.

The role of growth factors in the regulation of beta-cell mass has been extensively studied in rodent foetal and adult islets and information on human islet growth, potentially indicate that most beta cells in the human pancreas retain the capacity to proliferate in vitro under specific mitogenic stimuli [86]. Our results showing the expression of NGF and NGF receptors in human material agrees with previous data on human pancreatic cancer tissue; therefore, the two models and the experimental approaches used are not comparable [17-19].

The possibility to expand and maintain beta cells in vitro is the ultimate goal of beta-cell transplantation studies since the use of insulin secreting cells is an alternative approach to the classic therapy for diabetes mellitus. The source of cells is, however, a limiting factor. Human pancreatic islets are not easily available and large scale isolation of animal (such as porcine) islets present various difficulties. The use of beta-cell lines and the use of primary cultures of human beta cells is an attractive alternative because their proliferative potential and/or their resistance to proapoptotic stimuli could be regulated by engineering technologies, providing an unlimited source of cells and a more favourable fate of transplanted cells. Furthermore, the culture conditions before transplantation are extremely important to condition cell survival. We suggest that the integrity of $\mathrm{NGF} / \mathrm{NGF}$ receptor system in beta cells and NGF bioavailability in culture is important for beta-cell survival in pretransplantation conditions and therefore NGF is a candidate factor, among other growth factors, important for obtaining improved beta cells for transplantation.

Acknowledgements. The authors are especially thankful to Pr. Efrat (Tel Aviv, Israel) who provided the $\beta$ TC6-F7 cells and to Pr. Modesti (Rome, Italy) for critical discussion. For the Italian staff, this work was supported by MURST, CNR and NEFAC as well as Ph.D. fellowships from MURST to D. Pierucci, S. Cicconi and P. Bonini For the Swiss staff, financial support was from the Juvenile Diabetes Foundation International (Program Project Grant to P.Halban and J.Oberholzer).

\section{References}

1. Le Douarin NM (1988) On the origin of pancreatic endocrine cells. Cell 53: 169-171

2. Pearse AG (1969) The cytochemistry and ultrastructure of polypeptide hormone-producing cells of the APUD series and the embryologic, physiologic and pathologic implications of the concept. J Histochem Cytochem 17: 303-313

3. Pictet RL, Rall LB, Phelps P, Rutter WJ (1976) The neural crest and the origin of the insulin-producing and other gastrointestinal hormone-producing cells. Science 191: 191-192

4. De Camilli P, Jahn R (1990) Pathways to regulated exocytosis in neurons. Annu Rev Physiol 52: 625-645

5. Baekkeskov S, Aanstoot HJ, Christgau S et al. (1990) Identification of the $64 \mathrm{~K}$ autoantigen in insulin-dependent diabetes as the GABA-synthesizing enzyme glutamic acid decarboxylase [published erratum appears in Nature 1990;347: 782]. Nature 347: 151-156

6. Gonoi T, Mizuno N, Inagaki N et al. (1994) Functional neuronal ionotropic glutamate receptors are expressed in the non-neuronal cell line MIN6. J Biol Chem 269: 16989-16992

7. Philipson LH, Kusnetsov A, Larson T, Zeng Y, Westermark G (1993) Human, rodent, and canine pancreatic beta-cells express a sodium channel alpha 1-subunit related to a fetal brain isoform. Diabetes 42: 1372-1377

8. Teitelman G, Lee JK (1987) Cell lineage analysis of pancreatic islet development: glucagon and insulin cells arise from catecholaminergic precursors present in the pancreatic duct. Dev Biol 121: 454-466

9. Teitelman G, Lee J, Reis DJ (1987) Differentiation of prospective mouse pancreatic islet cells during development in vitro and during regeneration. Dev Biol 120: 425-433

10. Watanabe T, Nagatsu I (1991) Immunohistochemical colocalization of insulin, aromatic L-amino acid decarboxylase and dopamine beta-hydroxylase in islet B cells of chicken pancreas. Cell Tissue Res 263: 131-136

11. Levi-Montalcini R (1987) The nerve growth factor 35 years later. Science 237: 1154-1162

12. Levi-Montalcini R, Skaper SD, Dal Toso R, Petrelli L, Leon A (1996) Nerve growth factor: from neurotrophin to neurokine. Trends Neurosci 19: 514-520

13. Chao MV, Hempstead BL (1995) p75 and Trk: a two-receptor system. Trends Neurosci 18: 321-326

14. Polak M, Scharfmann R, Seilheimer B et al. (1993) Nerve growth factor induces neuron-like differentiation of an insulin-secreting pancreatic beta cell line. Proc Natl Acad Sci U S A 90: 5781-5785

15. Rosenbaum T, Vidaltamayo R, Sanchez-Herrera D, Hiriart M (1996) Nerve growth factor increases sodium current in pancreatic beta cells. J Memb Biol 153: 53-58

16. Kanaka-Gantenbein C, Dicou E, Czernichow P, Scharfmann R (1995) Presence of nerve growth factor and its receptors in an in vitro model of islet cell development: implication in normal islet morphogenesis. Endocrinology 136 : 3154-3162

17. Friess H, Zhu ZW, di Mola FF et al. (1999) Nerve growth factor and its high-affinity receptor in chronic pancreatitis. Ann Surg 230: 615-624

18. Shibayama E, Koizumi H (1996) Cellular localization of the Trk neurotrophin receptor family in human non-neuronal tissues. Am J Pathol 148: 1807-1818

19. Zhu Z, Friess H, diMola FF et al. (1999) Nerve growth factor expression correlates with perineural invasion and pain in human pancreatic cancer. J Clin Oncol 17: 2419-2428

20. Creedon DJ, Johnson EM, Lawrence JC (1996) Mitogenactivated protein kinase-independent pathways mediate 
the effects of nerve growth factor and cAMP on neuronal survival. J Biol Chem 271: 20713-20718

21. Xing J, Kornhauser JM, Xia Z, Thiele EA, Greenberg ME (1998) Nerve growth factor activates extracellular signalregulated kinase and p38 mitogen-activated protein kinase pathways to stimulate CREB serine 133 phosphorylation. Mol Cell Biol 18: 1946-1955

22. Xia Z, Dickens M, Raingeaud J, Davis RJ, Greenberg ME (1995) Opposing effects of ERK and JNK-p38 MAP kinases on apoptosis. Science 270: 1326-1331

23. Maggiwar SB, Ramirez S, Tong N, Gelbard HA, Dewhurst S (2000) Functional interplay between nuclear factor-kappaB and c-Jun integrated by coactivator p300 determines the survival of nerve growth factor-dependent PC12 cells. J Neurochem 74: 527-539

24. Kummer JL, Rao PK, Heidenreich KA (1997) Apoptosis induced by withdrawal of trophic factors is mediated by p38 mitogen-activated protein kinase. J Biol Chem 272: 20490-20494

25. Rosini P, De Chiara G, Lucibello M, Garaci E, Cozzolino F, Torcia M (2000) NGF withdrawal induces apoptosis in CESS B cell line through p38 MAPK activation and Bcl-2 phosphorylation. Biochem Biophys Res Commun 278: 753-759

26. Soltoff SP, Rabin SL, Cantley LC, Kaplan DR (1992) Nerve growth factor promotes the activation of phosphatidylinositol 3- kinase and its association with the trk tyrosine kinase. J Biol Chem 267: 17472-17477

27. Yan CYI, Greene LA (1998) Prevention of PC12 cell death by $\mathrm{N}$-acetylcysteine requires activation of the Ras pathway. J Neurosci 18: 4042-4049

28. Crowder RJ, Freeman RS (1998) Phosphatidylinositol 3-kinase and Akt protein kinase are necessary and sufficient for the survival of nerve growth factor-dependent sympathetic neurons. J Neurosci 18: 2933-2943

29. Zha J, Harada H, Yang E, Jockel J, Korsmeyer SJ (1996) Serine phosphorylation of death agonist BAD in response to survival factor results in binding to $14-3-3$ not BCLX(L). Cell 87: 619-628

30. Korsmeyer SJ (1999) BCL-2 gene family and the regulation of programmed cell death. Cancer Res 59: 1693S-1700S

31. del Peso L, Gonzalez-Garcia M, Page C, Herrera R, Nunez $\mathrm{G}$ (1997) Interleukin-3-induced phosphorylation of BAD through the protein kinase Akt. Science 278: 687-689

32. Yang E, Zha J, Jockel J, Boise LH, Thompson CB, Korsmeyer SJ (1995) Bad, a heterodimeric partner for Bcl-XL and Bcl-2, displaces Bax and promotes cell death. Cell 80: 285-291

33. Marchetti P, Giannarelli R, Cosimi S et al. (1995) Massive isolation, morphological and functional characterization, and xenotransplantation of bovine pancreatic islets [published erratum appears in Diabetes 1995 May;44: 601]. Diabetes 44: 375-381

34. Federici M, Hribal ML, Ranalli M et al. (2001) The common Arg972 polymorphism in insulin receptor substrate-1 causes apoptosis of human pancreatic islets. FASEB J 15: 22-24

35. Federici M, Hribal M, Perego L et al. (2001) High Glucose Causes Apoptosis in Cultured Human Pancreatic Islets of Langerhans: A Potential Role for Regulation of Specific Bcl Family Genes Toward an Apoptotic Cell Death Program. Diabetes 50: 1290-1301

36. Ricordi C, Lacy PE, Finke EH, Olack BJ, Scharp DW (1988) Automated method for isolation of human pancreatic islets. Diabetes 37: 413-420

37. Ricordi C, Gray DW, Hering BJ et al. (1990) Islet isolation assessment in man and large animals. Acta Diabetol Lat 27: 185-195
38. Meyer K, Irminger JC, Moss LG et al. (1998) Sorting human beta-cells consequent to targeted expression of green fluorescent protein. Diabetes 47: 1974-1977

39. Knaack D, Fiore DM, Surana M, Leiser M, Laurance M, Fusco-DeMane D et al. (1994) Clonal insulinoma cell line that stably maintains correct glucose responsiveness. Diabetes 43: 1413-1417

40. Porzio O, Marlier LN, Federici M et al. (1999) GLUT2 and glucokinase expression is coordinately regulated by sulfonylurea. Mol Cell Endocrinol 153: 155-161

41. Chomczynski P, Sacchi N (1987) Single-step method of RNA isolation by acid guanidinium thiocyanate- phenolchloroform extraction. Anal Biochem 162: 156-159

42. Salvatore AM, Cozzolino M, Gargano N, Galanti S, Levi A, Alema S (1995) Neuronal differentiation of P19 embryonal cells exhibits cell-specific regulation of neurotrophin receptors. Neuroreport 6: 873-877

43. Torcia M, Bracci-Laudiero L, Lucibello M et al. (1996) Nerve growth factor is an autocrine survival factor for memory B lymphocytes. Cell 85: 345-356

44. Borboni P, Magnaterra R, Rabini RA et al. (1996) Effect of biotin on glucokinase activity, mRNA expression and insulin release in cultured beta-cells. Acta Diabetol 33: 154-158

45. Cattaneo A, Rapposelli B, Calissano P (1988) Three distinct types of monoclonal antibodies after long-term immunization of rats with mouse nerve growth factor. J Neurochem 50: 1003-1010

46. Ruberti F, Bradbury A, Cattaneo A (1993) Cloning and expression of an anti-nerve growth factor (NGF) antibody for studies using the neuroantibody approach. Cell Mol Neurobiol 13: 559-568

47. Calza L, Giardino L, Pozza M, Bettelli C, Micera A, Aloe L (1998) Proliferation and phenotype regulation in the subventricular zone during experimental allergic encephalomyelitis: in vivo evidence of a role for nerve growth factor. Proc Natl Acad Sci U S A 95: 3209-3214

48. Canossa M, Twiss JL, Verity AN, Shooter EM (1996) p75(NGFR) and TrkA receptors collaborate to rapidly activate a p75(NGFR)-associated protein kinase. EMBO J 15: 3369-3376

49. Ohmichi M, Pang L, Ribon V, Gazit A, Levitzki A, Saltiel AR (1993) The tyrosine kinase inhibitor tyrphostin blocks the cellular actions of nerve growth factor. Biochemistry 32: 4650-4658

50. Nicoletti I, Migliorati G, Pagliacci MC, Grignani F, Riccardi C (1991) A rapid and simple method for measuring thymocyte apoptosis by propidium iodide staining and flow cytometry. J Immunol Methods 139: 271-279

51. Iwahashi H, Hanafusa T, Eguchi Y et al. (1996) Cytokineinduced apoptotic cell death in a mouse pancreatic betacell line: inhibition by Bcl-2. Diabetologia 39: 530-536

52. Teitelman G, Guz Y, Ivkovic S, Ehrlich M (1998) Islet injury induces neurotrophin expression in pancreatic cells and reactive gliosis of peri-islet Schwann cells. J Neurobiol 34: 304-318

53. Miralles F, Philippe P, Czernichow P, Scharfmann R (1998) Expression of nerve growth factor and its high-affinity receptor Trk-A in the rat pancreas during embryonic and fetal life. J Endocrinol 156: 431-439

54. Rosenbaum T, Vidaltamayo R, Sanchez-Soto MC, Zentella A, Hiriart M (1998) Pancreatic beta cells synthesize and secrete nerve growth factor. Proc Natl Acad Sci U S A 95: 7784-7788

55. Kanaka-Gantenbein C, Dicou E, Czernichow P, Scharfmann R (1995) Presence of nerve growth factor and its receptors in an in vitro model of islet cell development: impli- 
cation in normal islet morphogenesis. Endocrinology 136: 3154-3162

56. Scharfmann R, Atouf F, Tazi A, Czernichow P (1994) Growth hormone and prolactin regulate the expression of nerve growth factor receptors in INS-1 cells. Endocrinology 134: 2321-2328

57. Scharfmann R, Tazi A, Polak M, Kanaka C, Czernichow P (1993) Expression of functional nerve growth factor receptors in pancreatic beta-cell lines and fetal rat islets in primary culture. Diabetes 42: 1829-1836

58. Tazi A, Czernichow P, Scharfmann R (1995) Similarities and discrepancies in the signaling pathway for nerve growth factor in an insulin producing cell line and a neural crest-derived cell line. J Neuroendocrinol 7: 29-36

59. Edwards SN, Tolkovsky AM (1994) Characterization of apoptosis in cultured rat sympathetic neurons after nerve growth factor withdrawal. J Cell Biol 124: 537-546

60. Soilu-Hanninen M, Ekert P, Bucci T, Syroid D, Bartlett PF, Kilpatrick TJ (1999) Nerve growth factor signaling through p75 induces apoptosis in Schwann cells via a Bcl-2-independent pathway. J Neurosci 19: 4828-4838

61. Casaccia-Bonnefil P, Carter BD, Dobrowsky RT, Chao MV (1996) Death of oligodendrocytes mediated by the interaction of nerve growth factor with its receptor $\mathrm{p} 75$. Nature 383: 716-719

62. Casaccia-Bonnefil P, Gu C, Khursigara G, Chao MV (1999) p75 neurotrophin receptor as a modulator of survival and death decisions. Microsc Res Tech 45: 217-224

63. Bamji SX, Majdan M, Pozniak CD, Belliveau DJ, Aloyz R, Kohn J et al. (1998) The p75 neurotrophin receptor mediates neuronal apoptosis and is essential for naturally occurring sympathetic neuron death. J Cell Biol 140: 911-923

64. Bredesen DE, Rabizadeh S (1997) p75NTR and apoptosis: Trk-dependent and Trk-independent effects. Trends Neurosci 20: 287-290

65. Kaplan DR, Miller FD (1997) Signal transduction by the neurotrophin receptors. Curr Opin Cell Biol 9: 213-221

66. Mukai J, Hachiya T, Shoji-Hoshino S et al. (2000) NADE, a p75NTR-associated cell death executor, is involved in signal transduction mediated by the common neurotrophin receptor p75NTR. J Biol Chem 275: 17566-17570

67. Woodnutt DA, Wager-Miller J, O’Neill PC, Bothwell M, Byers MR (2000) Neurotrophin receptors and nerve growth factor are differentially expressed in adjacent nonneuronal cells of normal and injured tooth pulp. Cell Tissue Res 299: 225-236

68. Kummer JL, Rao PK, Heidenreich KA (1997) Apoptosis induced by withdrawal of trophic factors is mediated by p38 mitogen-activated protein kinase. J Biol Chem 272: 20490-20494

69. Barrett GL, Georgiou A (1996) The low-affinity nerve growth factor receptor p75NGFR mediates death of PC12 cells after nerve growth factor withdrawal. J Neurosci Res 45: $117-128$

70. Pincelli C, Haake AR, Benassi L et al. (1997) Autocrine nerve growth factor protects human keratinocytes from apoptosis through its high affinity receptor (TRK): a role for BCL-2. J Invest Dermatol 109: 757-764

71. Batistatou A, Greene LA (1993) Internucleosomal DNA cleavage and neuronal cell survival/death. J Cell Biol 122: $523-532$
72. Aloyz RS, Bamji SX, Pozniak CD et al. (1998) p53 is essential for developmental neuron death as regulated by the TrkA and p75 neurotrophin receptors. J Cell Biol 143: 1691-1703

73. Park DS, Morris EJ, Stefanis L et al. (1998) Multiple pathways of neuronal death induced by DNA-damaging agents, NGF deprivation, and oxidative stress. J Neurosci 18: 830-840

74. Borboni P, Porzio O, Magnaterra R et al. (1996) Quantitative analysis of pancreatic glucokinase gene expression in cultured beta cells by competitive polymerase chain reaction. Mol Cell Endocrinol 117: 175-181

75. Leist M, Gantner F, Bohlinger I, Germann PG, Tiegs G, Wendel A (1994) Murine hepatocyte apoptosis induced in vitro and in vivo by TNF-alpha requires transcriptional arrest. J Immunol 153: 1778-1788

76. Pittman RN, Wang S, DiBenedetto AJ, Mills JC (1993) A system for characterizing cellular and molecular events in programmed neuronal cell death. J Neurosci 13: 3669-3680

77. Schulz JB, Bremen D, Reed JC et al. (1997) Cooperative interception of neuronal apoptosis by BCL-2 and BAG-1 expression: prevention of caspase activation and reduced production of reactive oxygen species. J Neurochem 69: 2075-2086

78. Edwards SN, Buckmaster AE, Tolkovsky AM (1991) The death programme in cultured sympathetic neurones can be suppressed at the posttranslational level by nerve growth factor, cyclic AMP, and depolarization. J Neurochem 57: 2140-2143

79. Schurmann A, Mooney AF, Sanders LC et al. (2000) p21activated kinase 1 phosphorylates the death agonist bad and protects cells from apoptosis. Mol Cell Biol 20: 453-461

80. Carter AN, Downes CP (1992) Phosphatidylinositol 3-kinase is activated by nerve growth factor and epidermal growth factor in PC12 cells [published erratum appears in J Biol Chem 1992; 267: 23434]. J Biol Chem 267: 14563-14567

81. Crowder RJ, Freeman RS (1998) Phosphatidylinositol 3-kinase and Akt protein kinase are necessary and sufficient for the survival of nerve growth factor-dependent sympathetic neurons. J Neurosci 18: 2933-2943

82. Datta SR, Katsov A, Hu L et al. (2000) 14-3-3 proteins and survival kinases cooperate to inactivate BAD by $\mathrm{BH} 3$ domain phosphorylation. Mol Cell 6: 41-51

83. Eilers A, Whitfield J, Babij C, Rubin LL, Ham J (1998) Role of the Jun kinase pathway in the regulation of c-Jun expression and apoptosis in sympathetic neurons. J Neurosci 18: 1713-1724

84. Shimoke K, Yamagishi S, Yamada M, Ikeuchi T, Hatanaka H (1999) Inhibition of phosphatidylinositol 3-kinase activity elevates c-Jun $\mathrm{N}$ - terminal kinase activity in apoptosis of cultured cerebellar granule neurons. Brain Res Dev Brain Res 112: 245-253

85. Bonny C, Oberson A, Negri S, Sauser C, Schorderet DF (2001) Cell-permeable peptide inhibitors of JNK: novel blockers of beta-cell death. Diabetes 50: 77-82

86. Scharfmann R, Czernichow P (1996) Differentiation and growth of pancreatic beta cells. Diabetes Metab 22: 223-228 